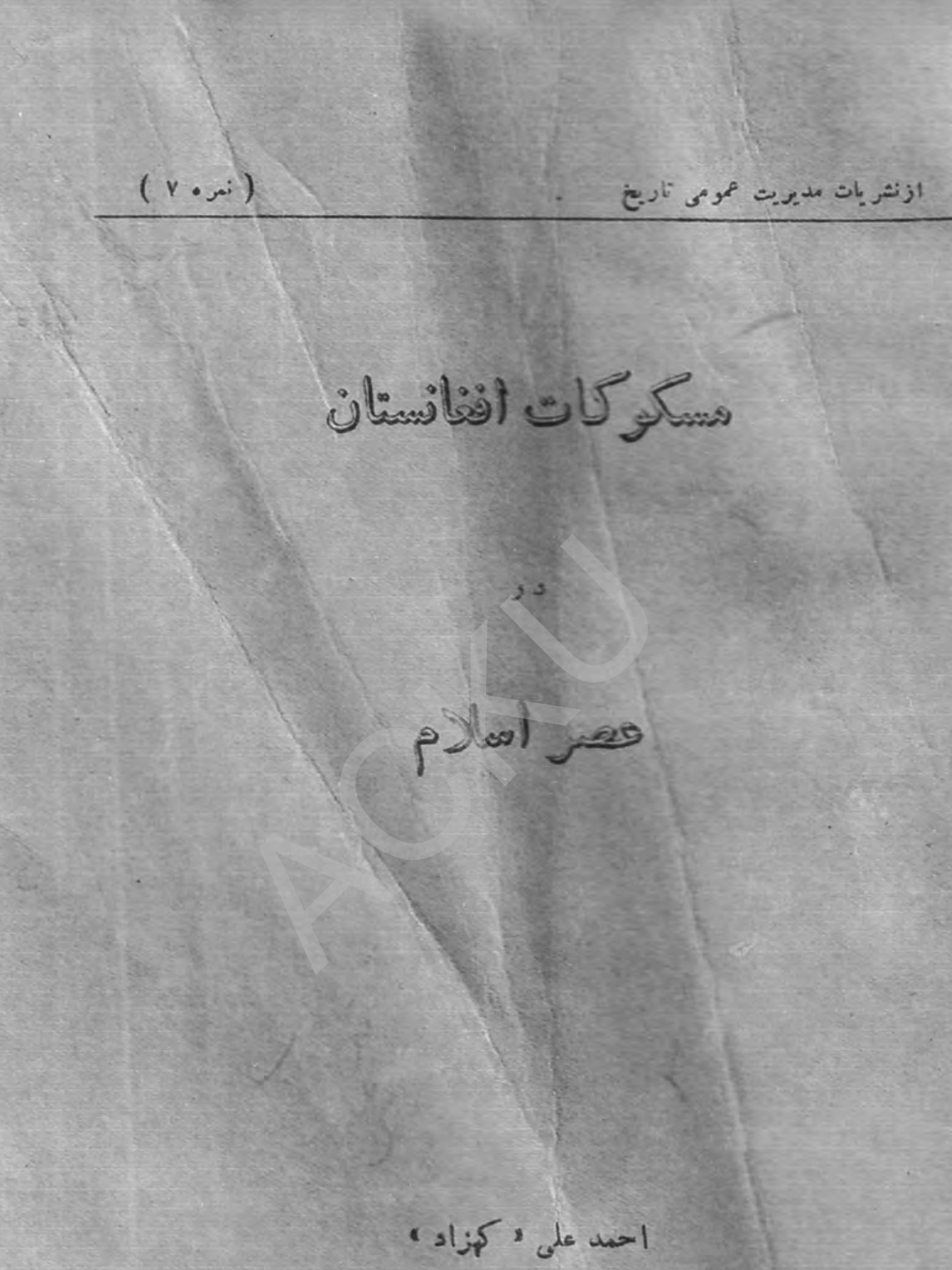




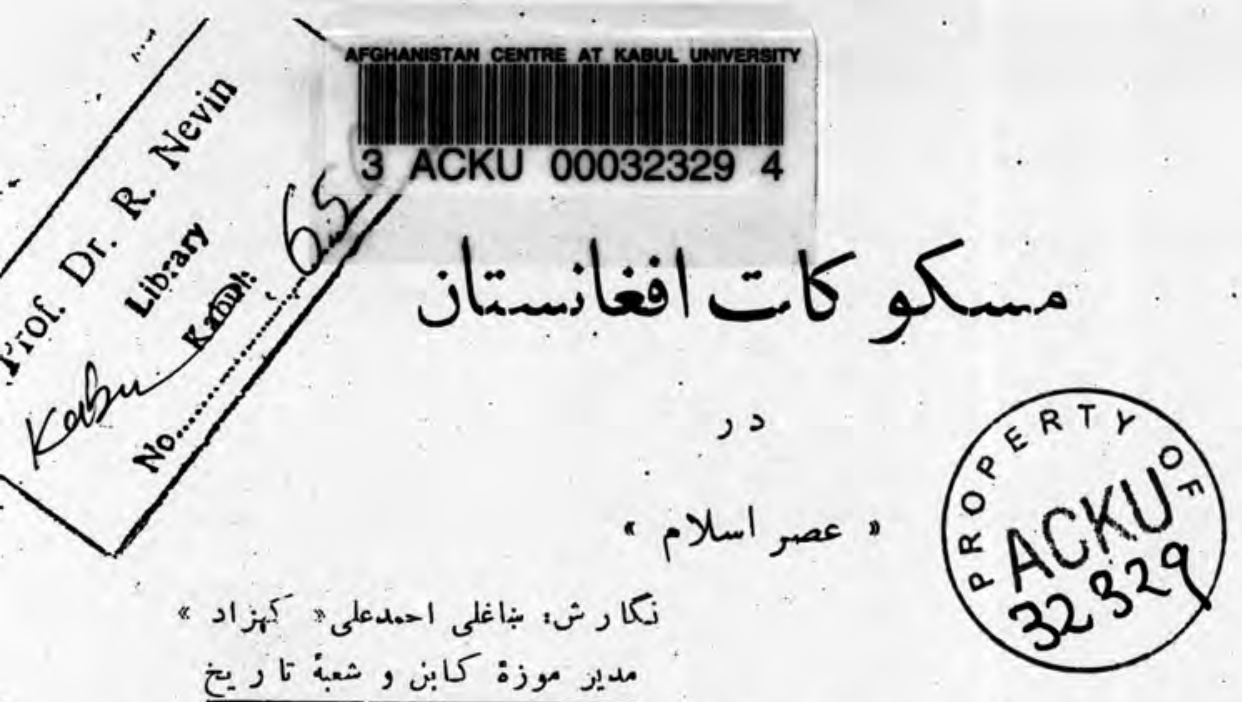

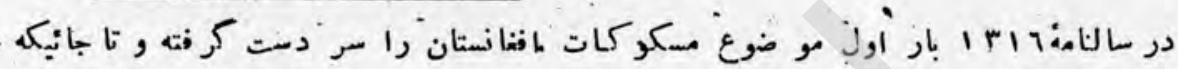

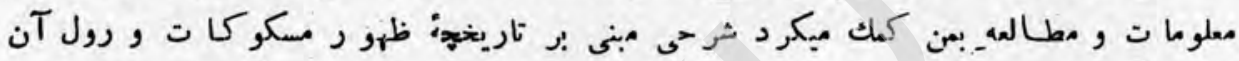

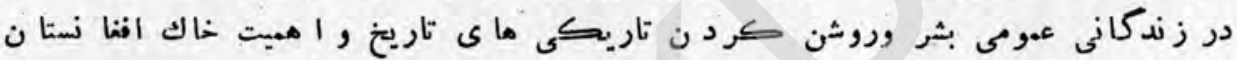

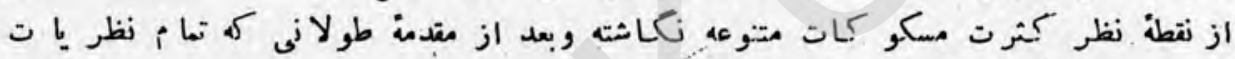

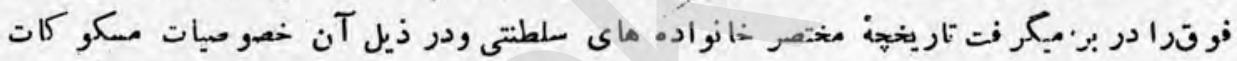

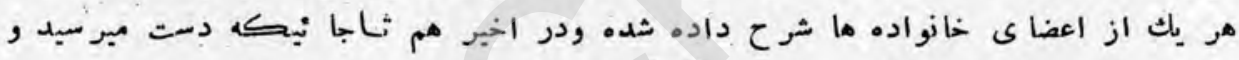

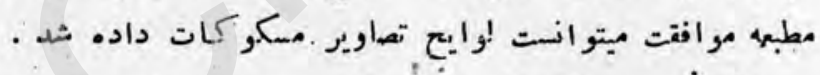

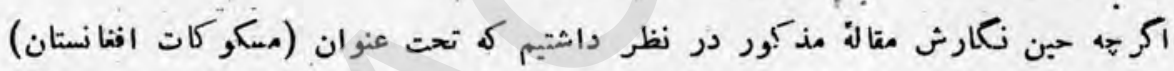

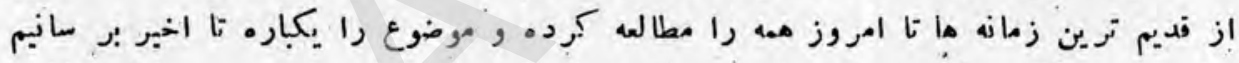

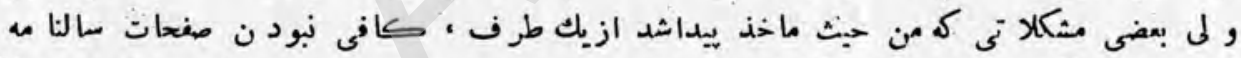

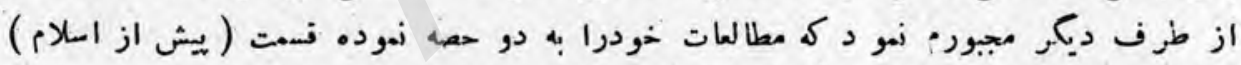

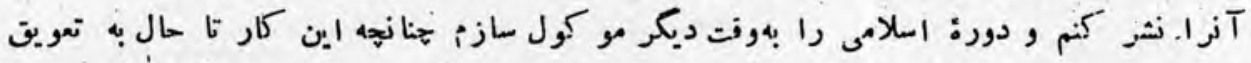

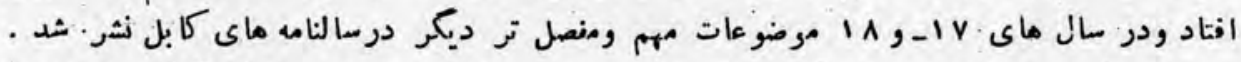

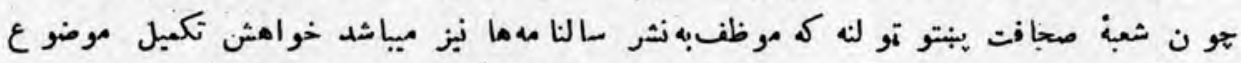

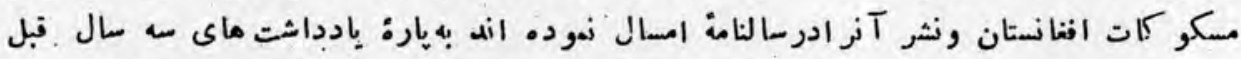

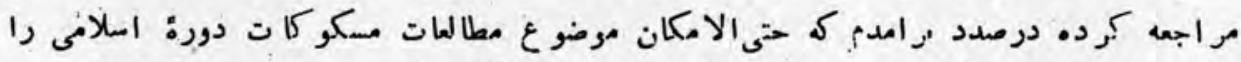

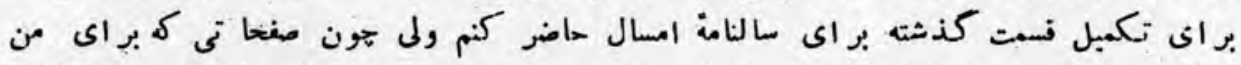

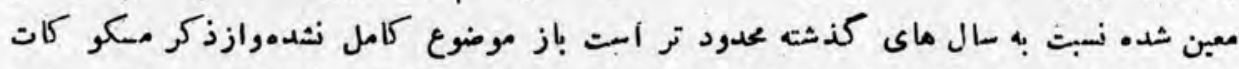

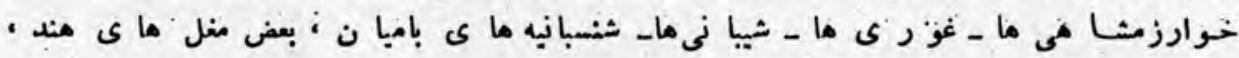




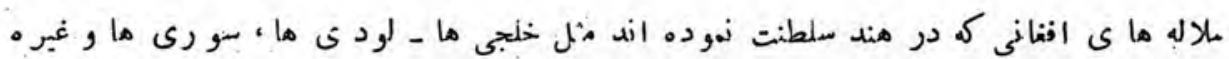

G

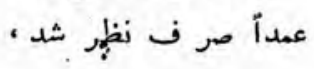
6 क

Lا.

نصر بن احهد : سه مسكواث نقرمنى اوكى بدست آمده ور درموزذ ينجاب حفظ است وراجد

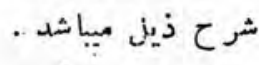
:

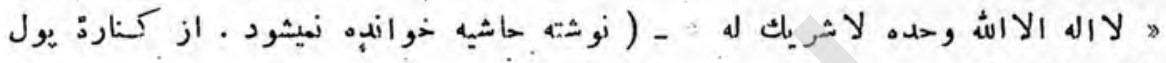
كمى شكسته است (

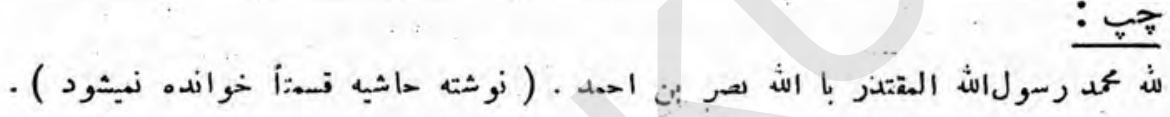
:

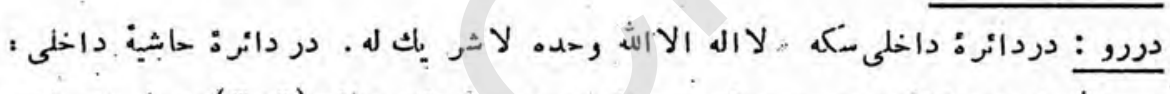

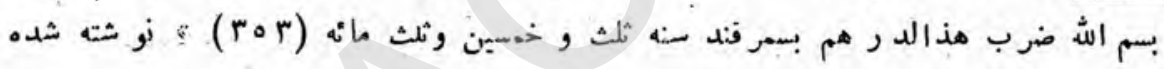

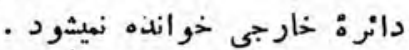

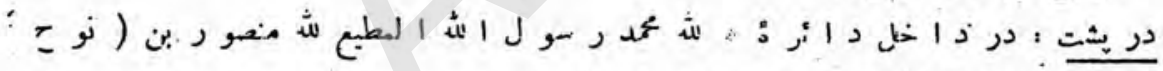

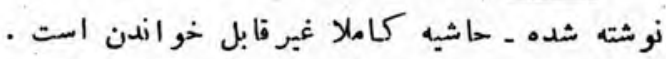

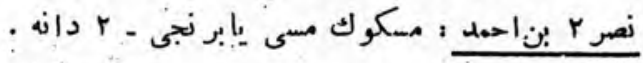

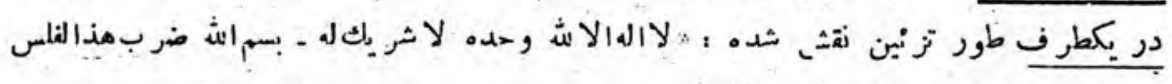

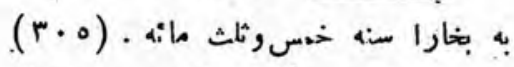

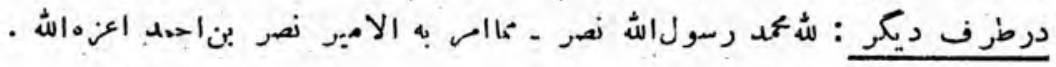

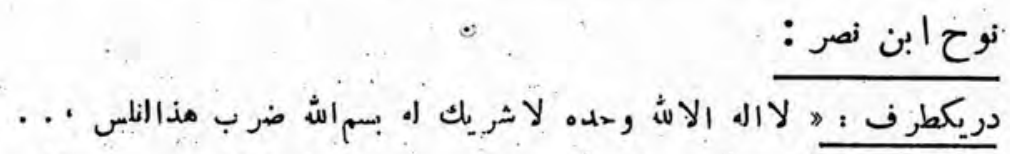

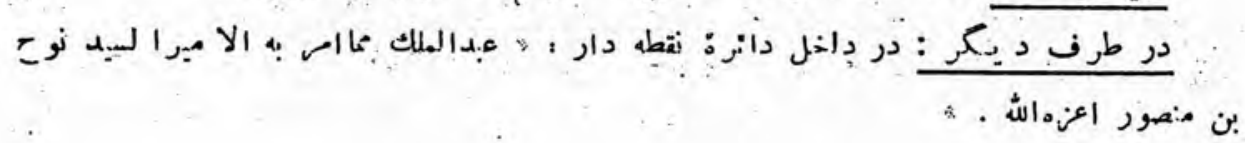




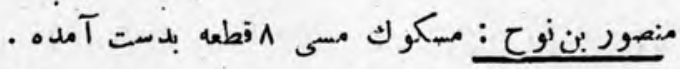

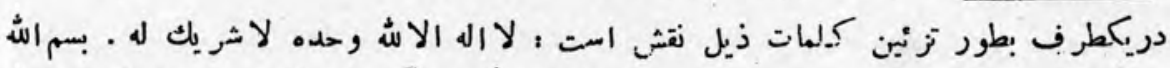

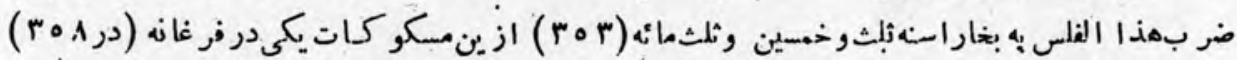

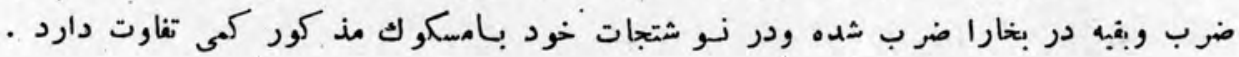

$$
\text { نوح بن منصور }
$$

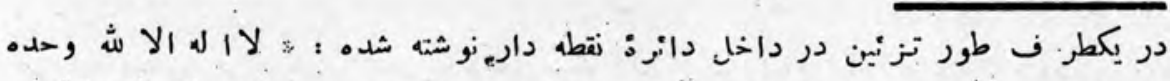

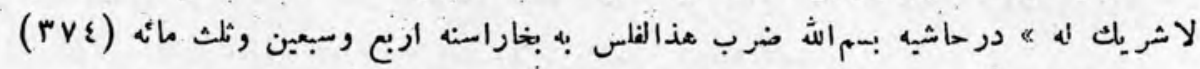

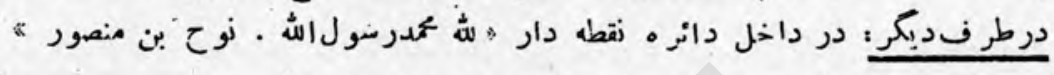

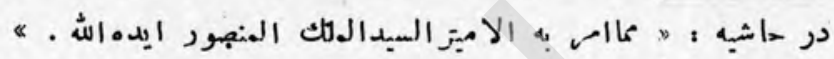

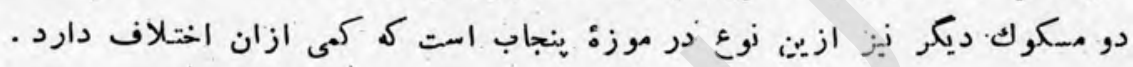

$$
\begin{aligned}
& \text { غن } \\
& \text { مسك. ك نقر ن }
\end{aligned}
$$

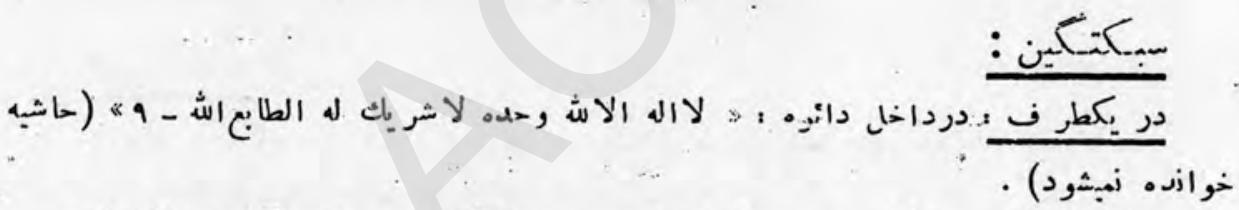

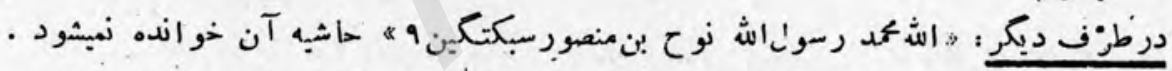

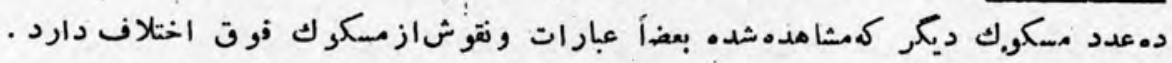

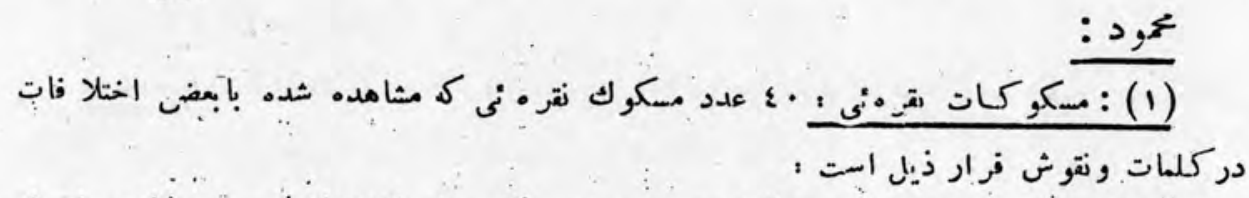

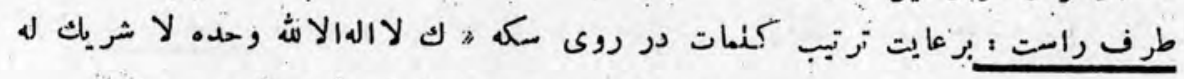

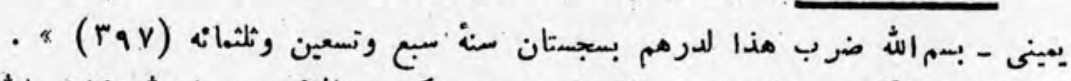

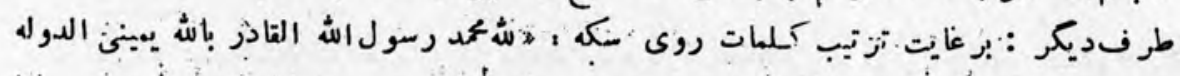

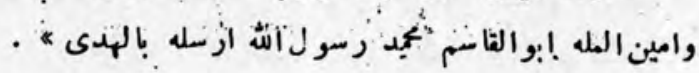




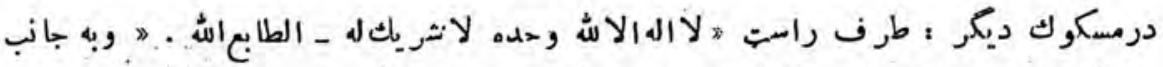

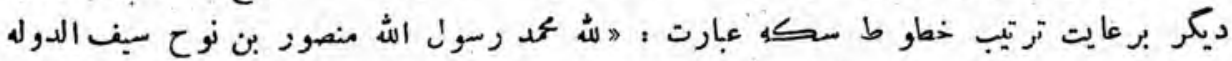

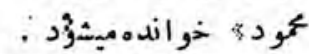

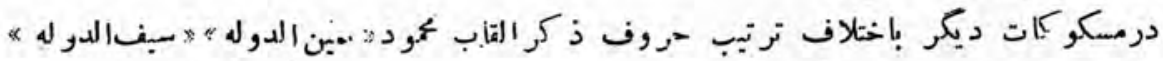

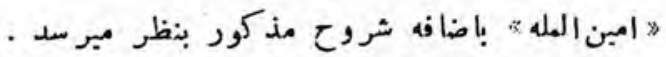

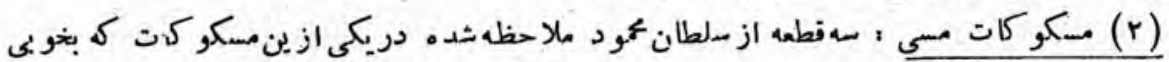

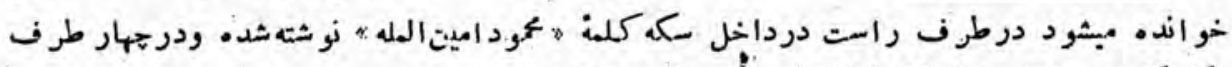

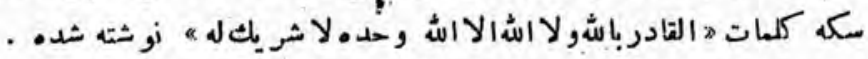

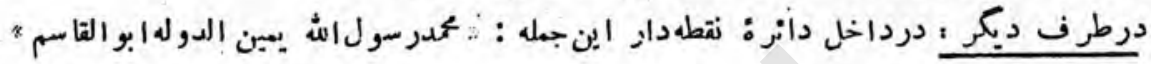

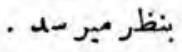

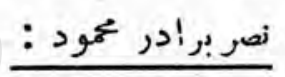

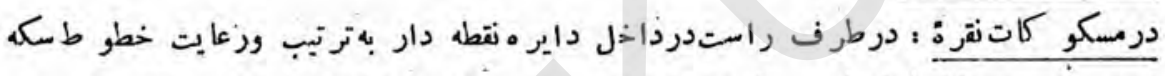

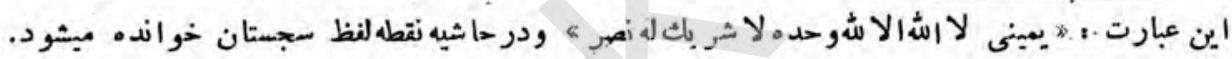

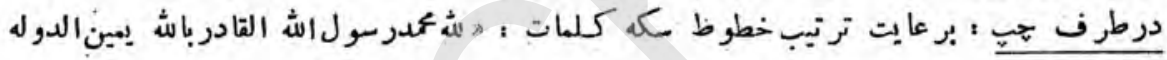

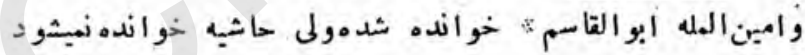

…

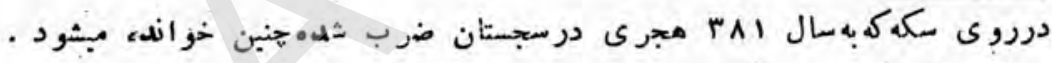

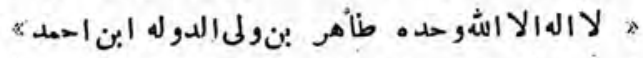

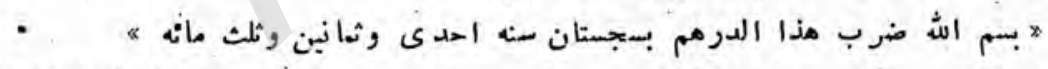

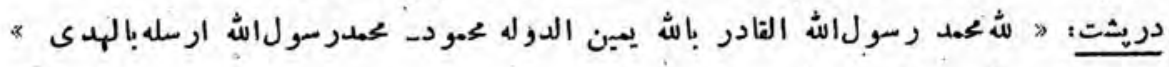

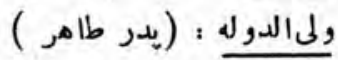

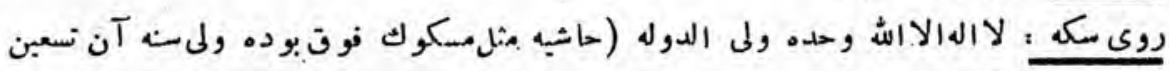

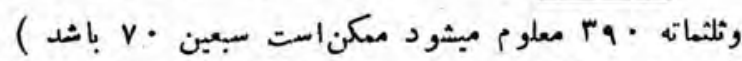

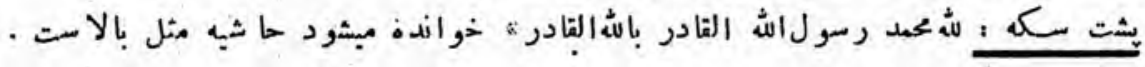
مسعود:

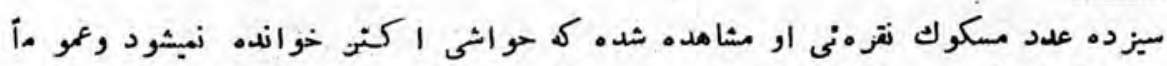

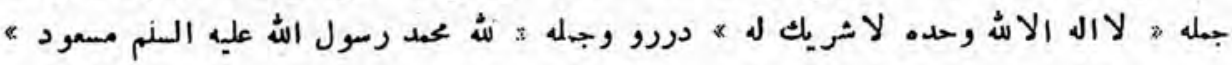




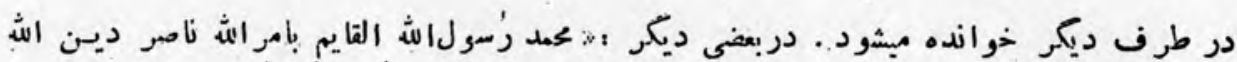

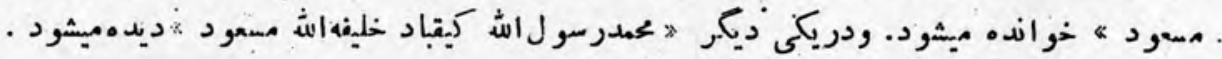

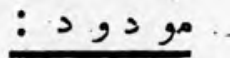

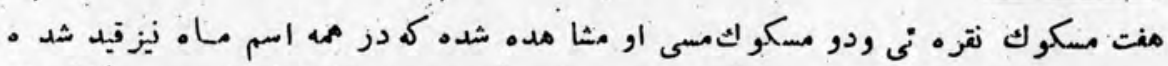

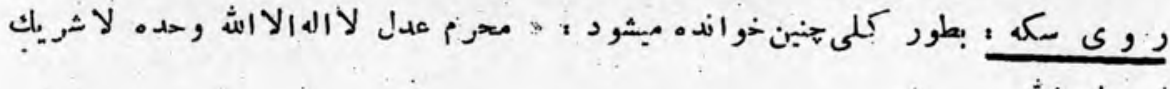

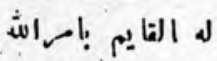

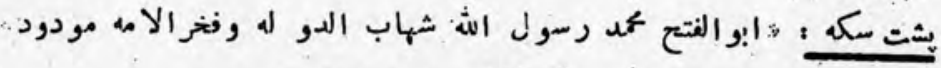

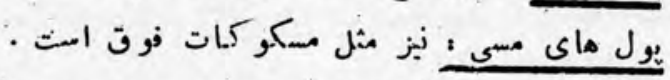

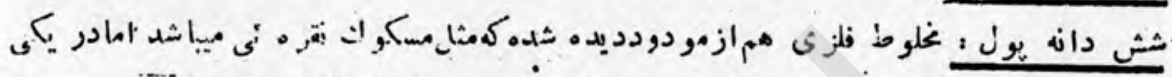

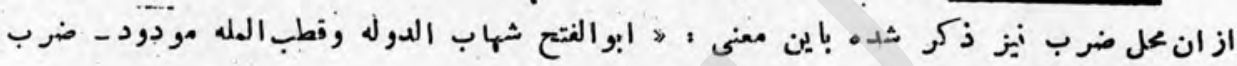

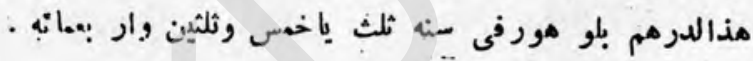

\section{عبالر شيد:}

يازده دانه همكوك مخلوط فلزى ازو ديده شده كم باختلاف كمى در عبارات و اشكال

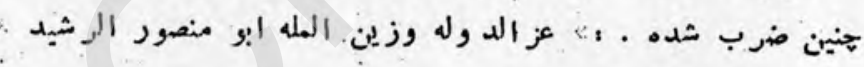

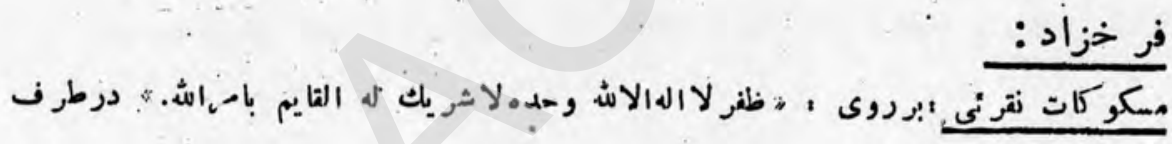

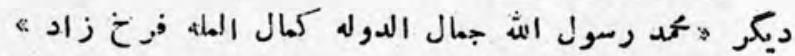

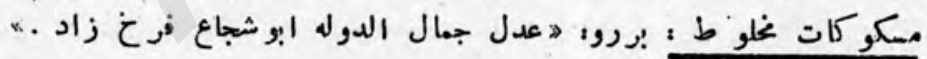

\section{6}

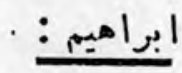

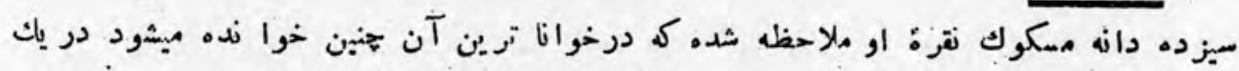

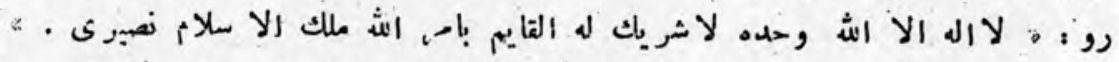

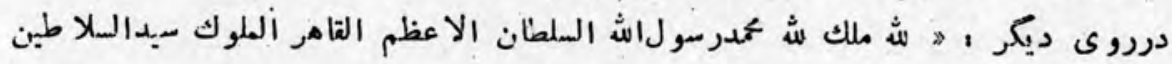

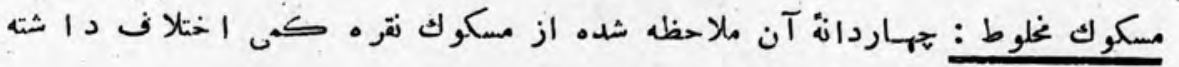

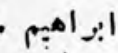
ودريكى جاى ضرب ( لاهور ) نيز قيه شده است . 


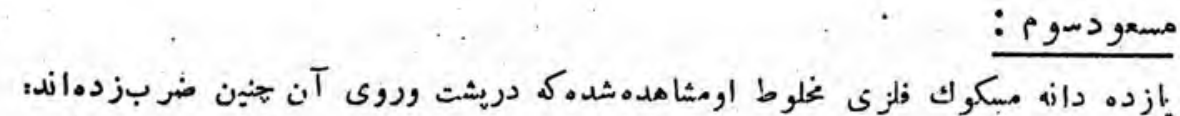

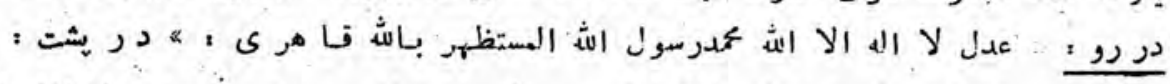

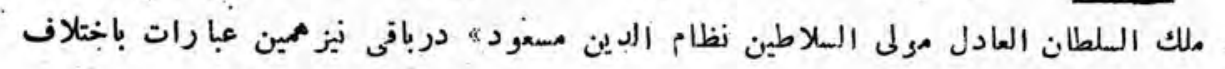

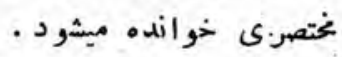

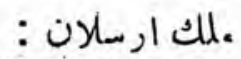

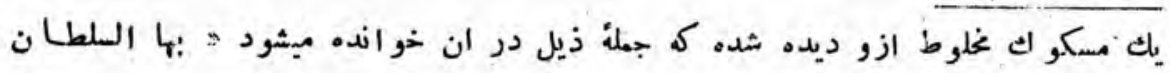

الا عظم ملك ارسلان

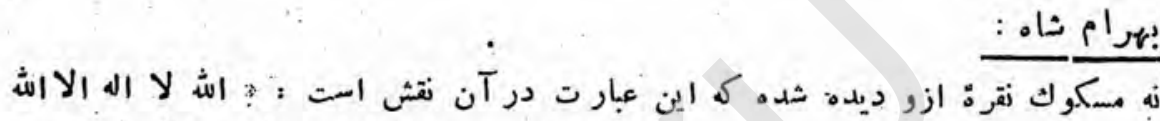

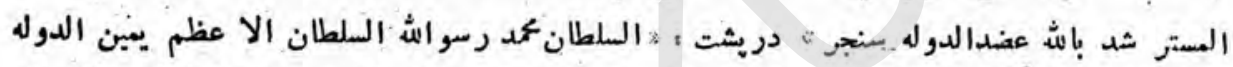

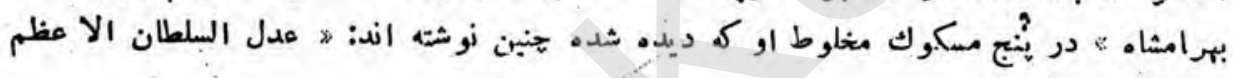
بـان:

خسرو شاه:

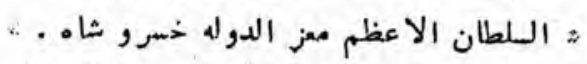
:

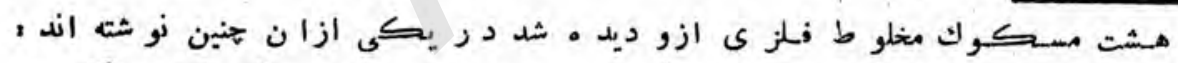

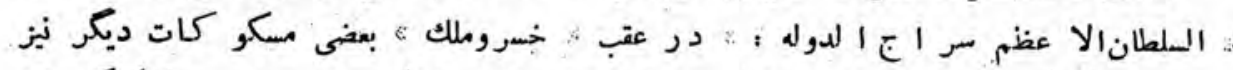

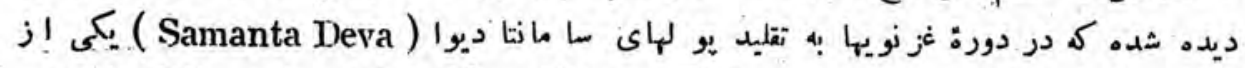

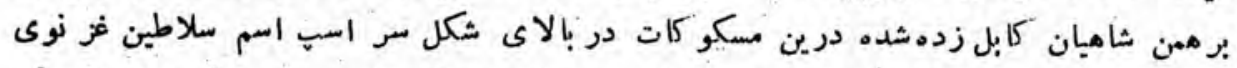

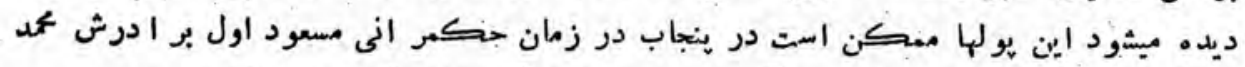

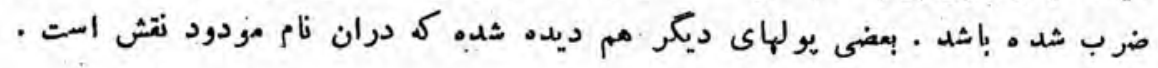

\section{Lo 1 (s,}

تيمورى ها در طلا ونقر ه ومس سكه زده اند روى هم رفته از اركان مهم اين خاندان

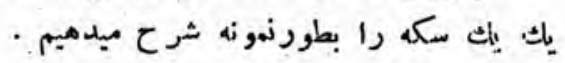




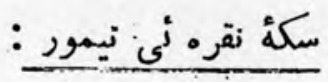

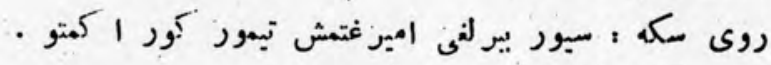

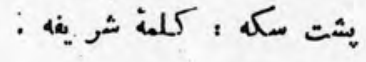

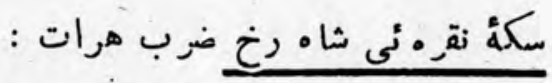

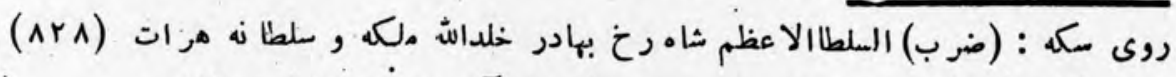

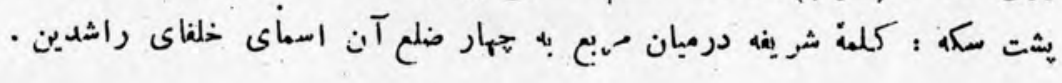

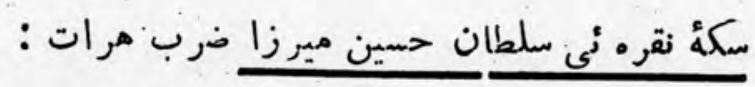

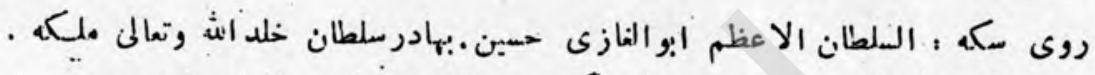

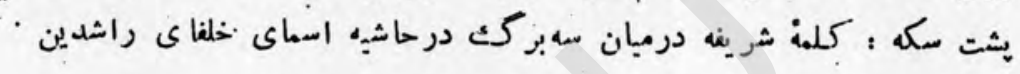

\section{- هi is}

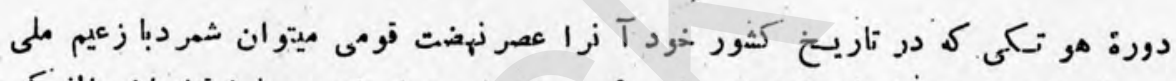

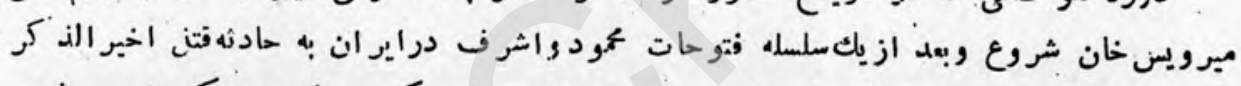

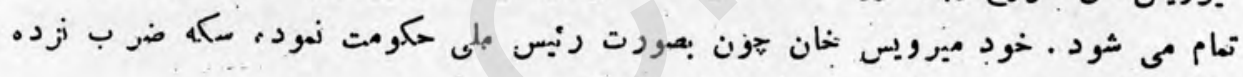

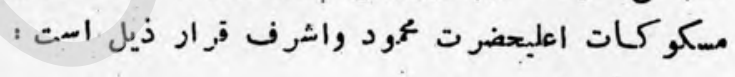

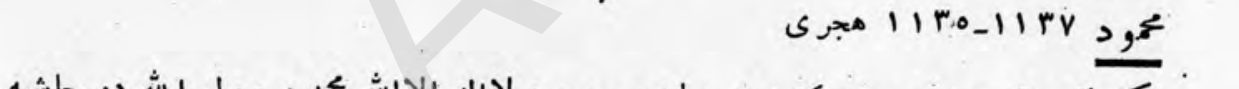

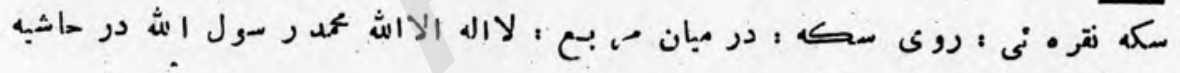

$$
\begin{aligned}
& \text { سكه زد از مشرق اير ان توفر مص افتاب }
\end{aligned}
$$

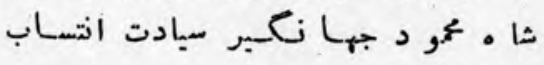

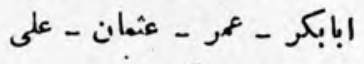

$$
\begin{aligned}
& \text { : }
\end{aligned}
$$

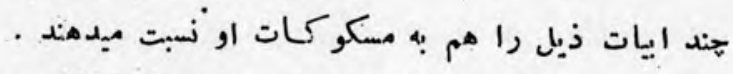

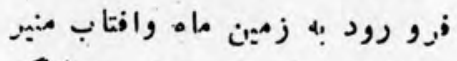

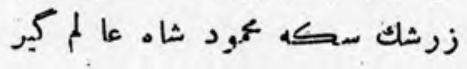

$$
\begin{aligned}
& \text { (1) की } \\
& \text { دين حق را سكه برزر كرد از حكم اله }
\end{aligned}
$$

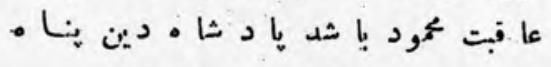




$$
\text { اثرف }
$$

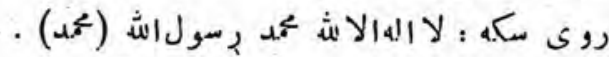

شرفز زكهاشر ف بهافتابرسيد

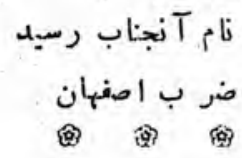

:ثشت سكه :

$$
\therefore \text { : }
$$

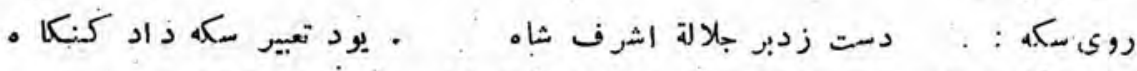

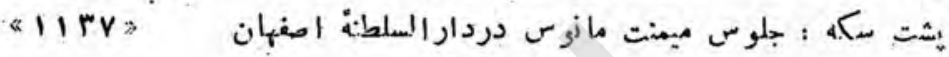

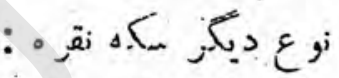

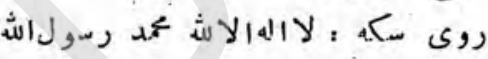

$$
\begin{aligned}
& \text { ضرب اهفهان }
\end{aligned}
$$

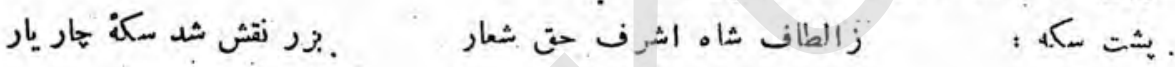

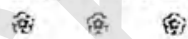

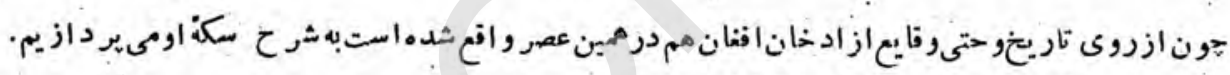

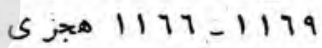

از ادخان

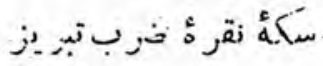

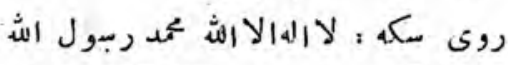

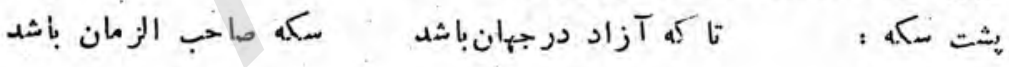

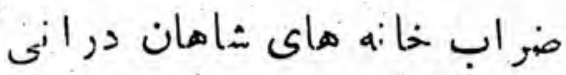

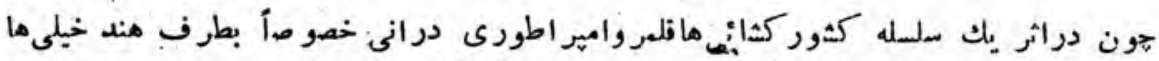

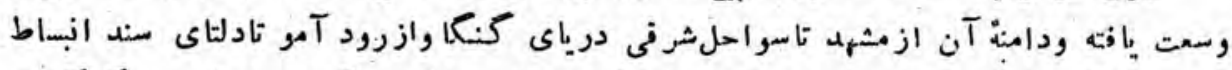

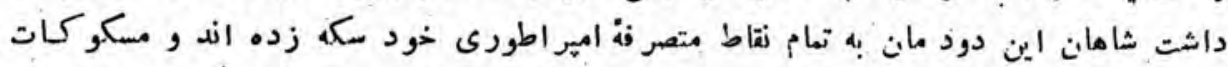

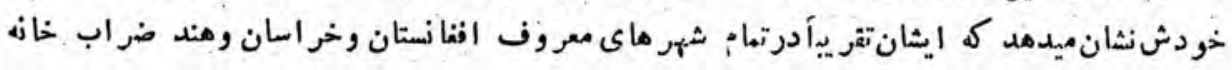

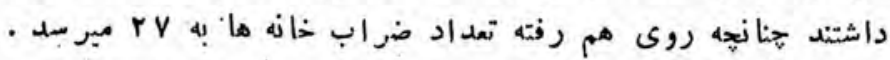

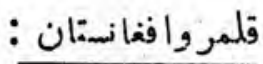

درانى ها درحوضة خاك افنفانستان. فعلى در هرات ، بلخ ، قندهار ( احمد شاهى ) كا بل 


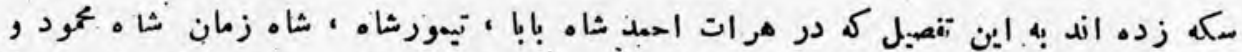

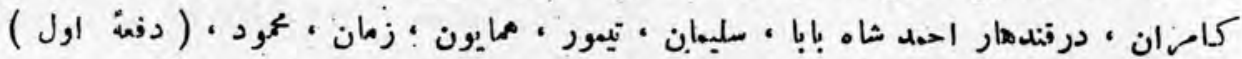

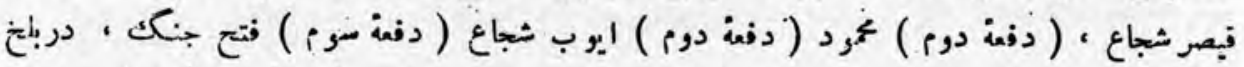

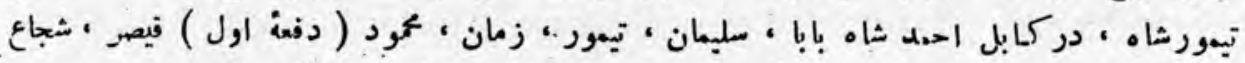

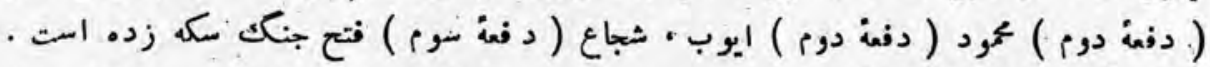

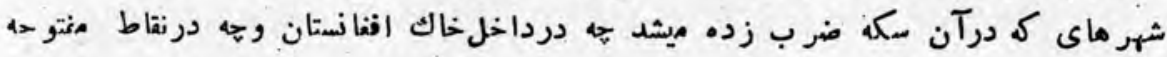

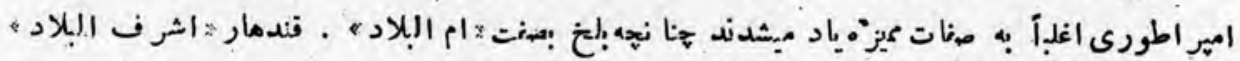

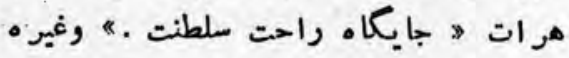

$$
\text { درإن إنران }
$$

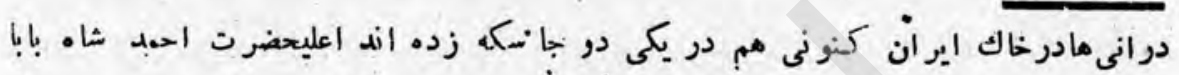

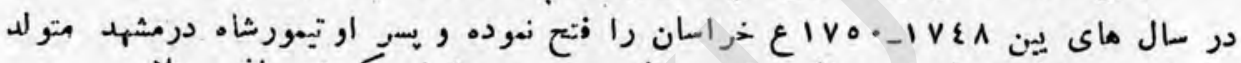

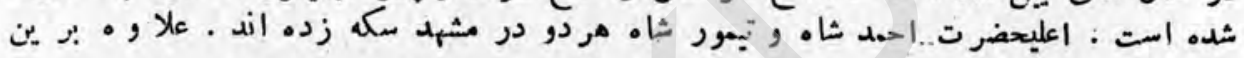

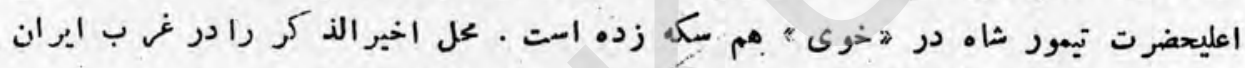

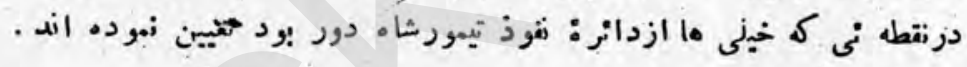

$$
\underline{\text { : } 20}
$$

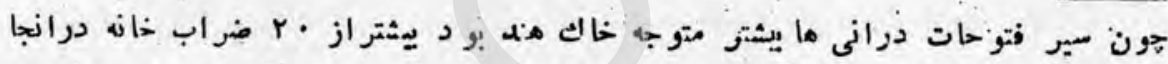

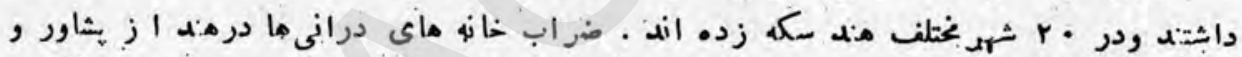

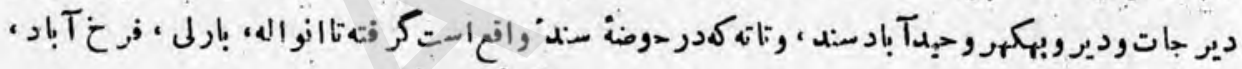

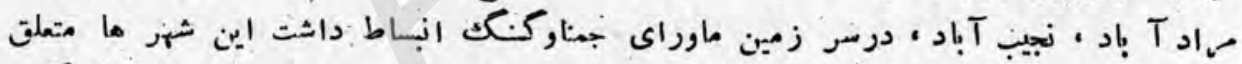

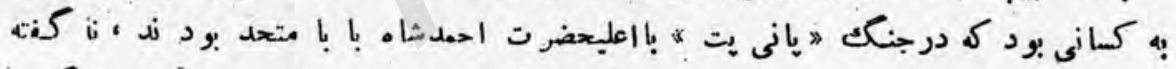

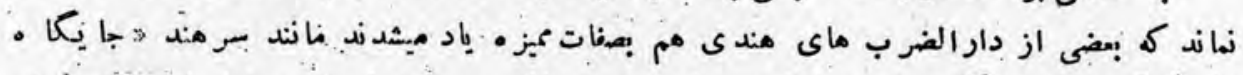

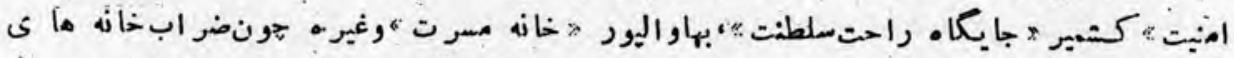

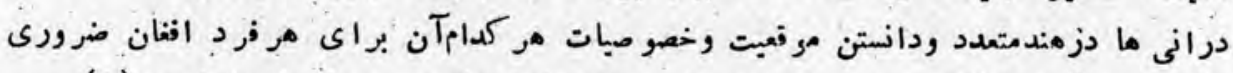

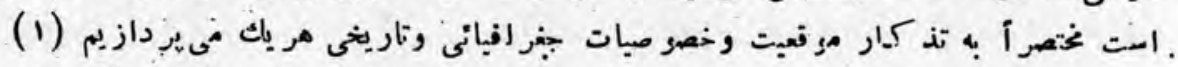

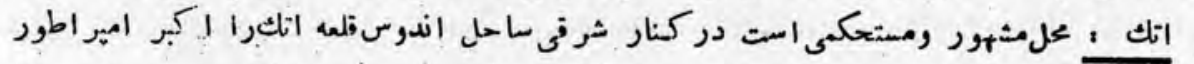

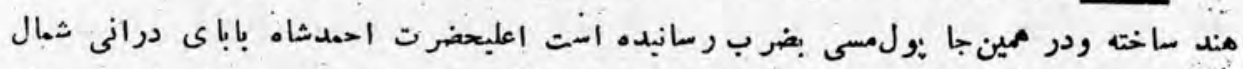

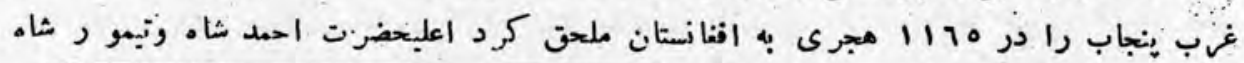

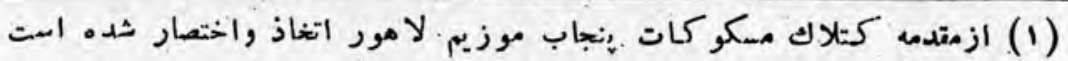


مسكوكات طلا ونقر. دراتك ضرب كرده اند.

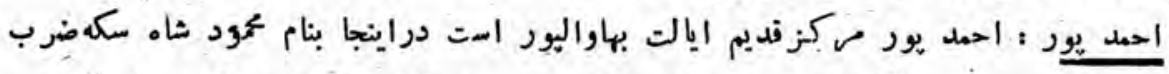

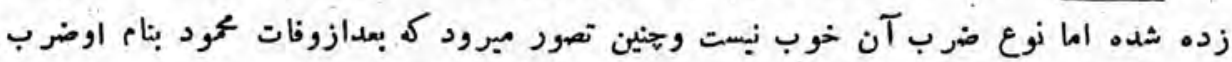
زده شده باشد . زيد المع

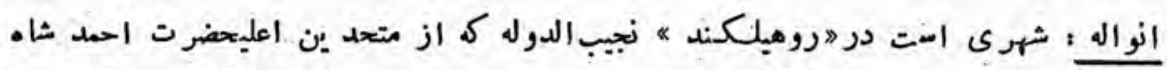

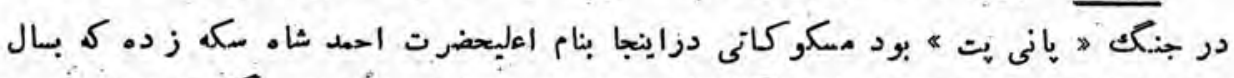

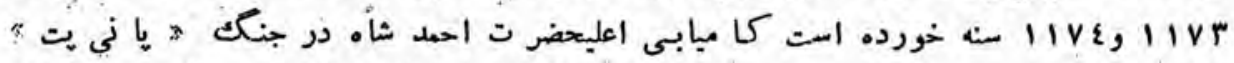

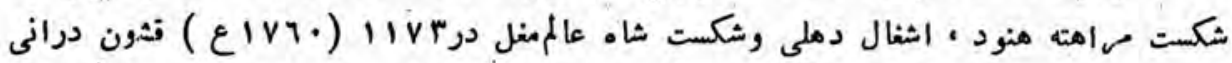

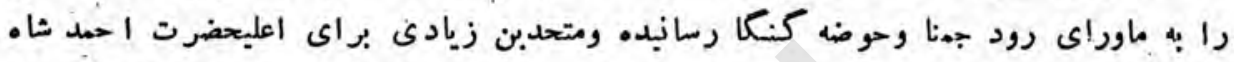

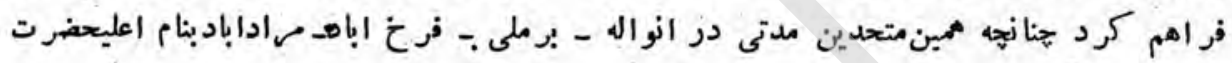

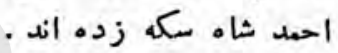

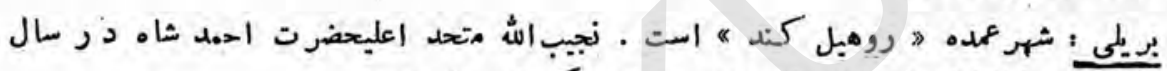
هiأى

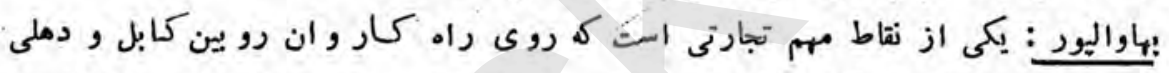

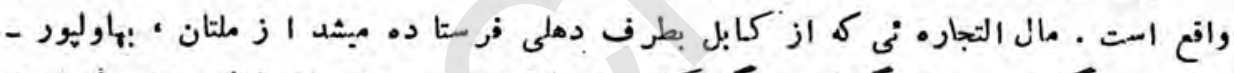

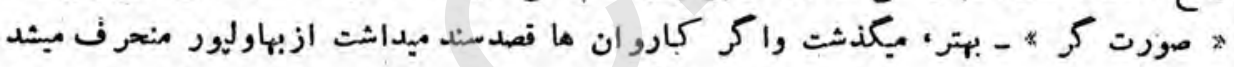

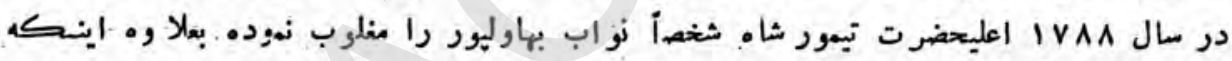

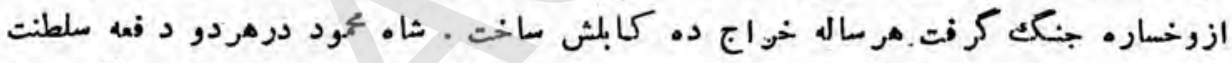

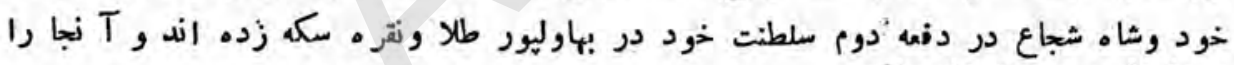

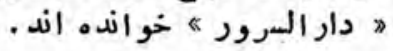

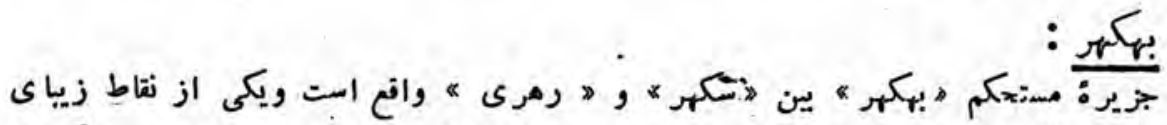

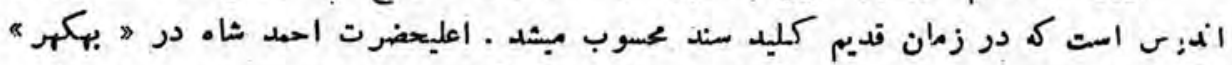

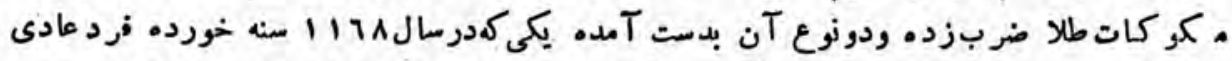

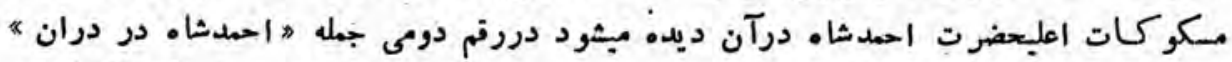

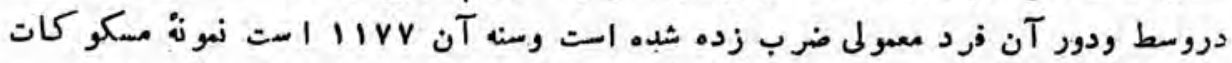

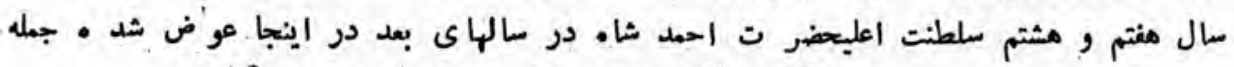

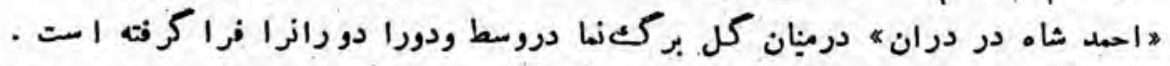

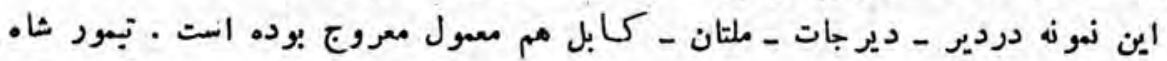




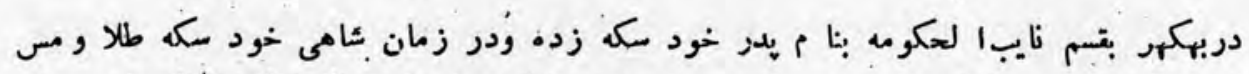

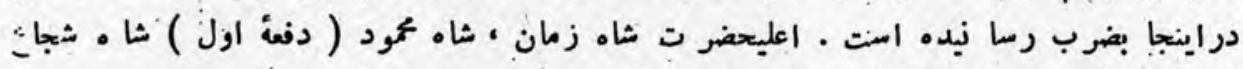

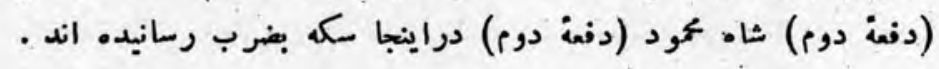

\section{:}

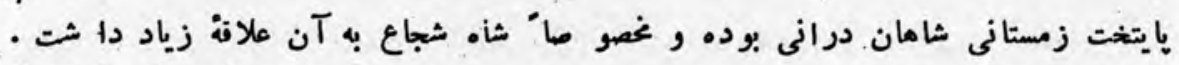

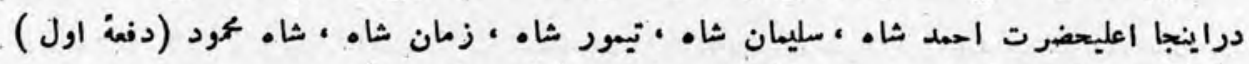

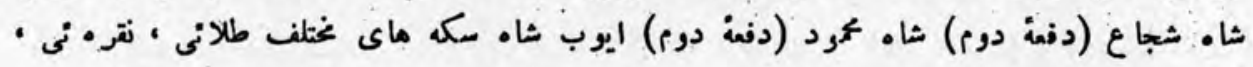

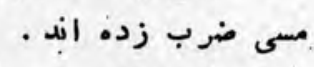

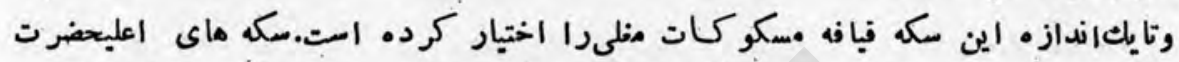

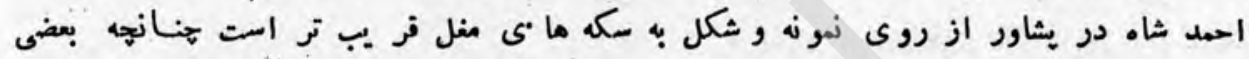

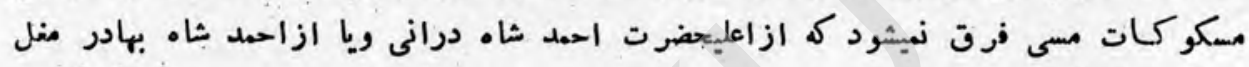

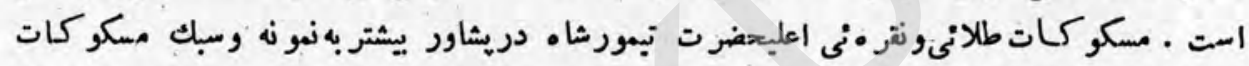

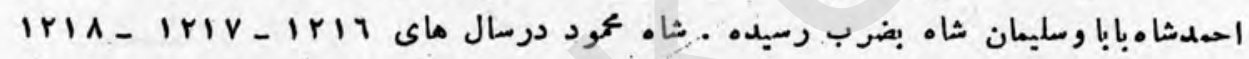
دراينجا سكه زدماه ومانمان

تتهـه:

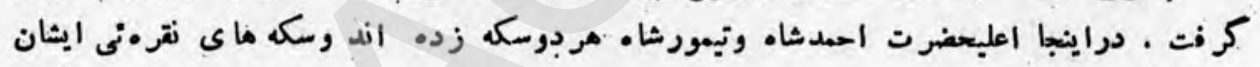

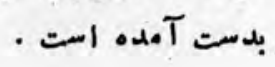

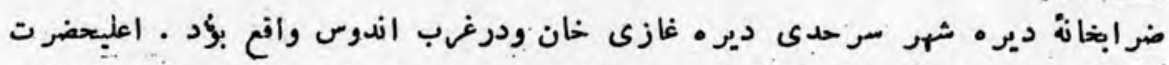

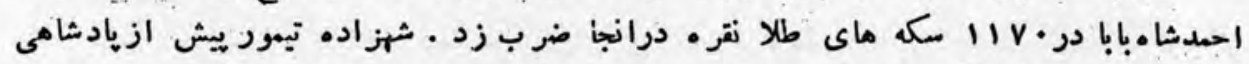

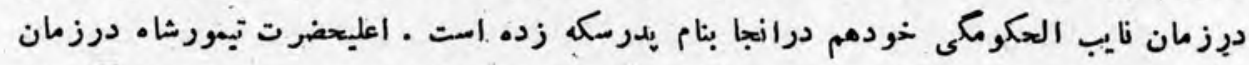

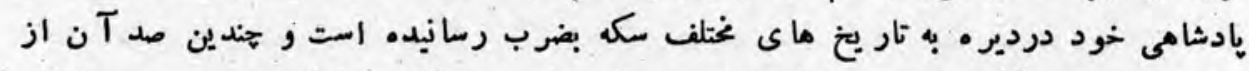

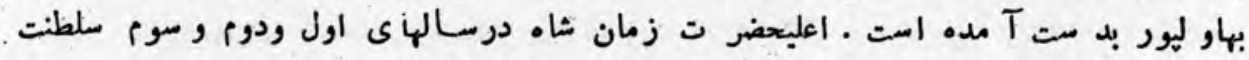

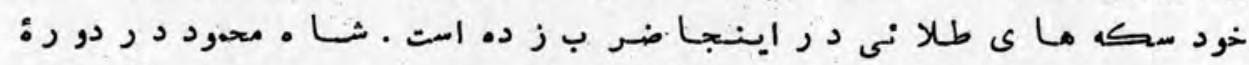

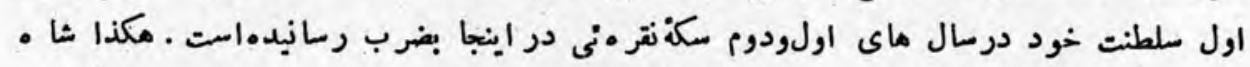

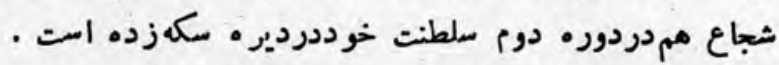




\section{ديرِ}

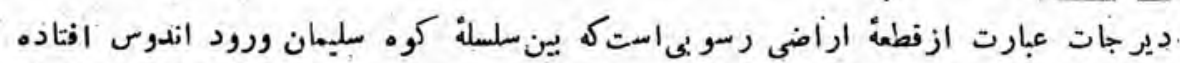

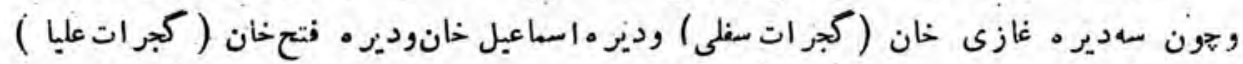

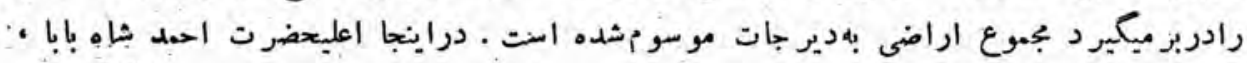

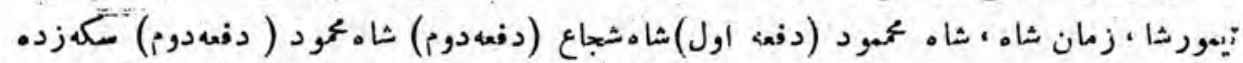

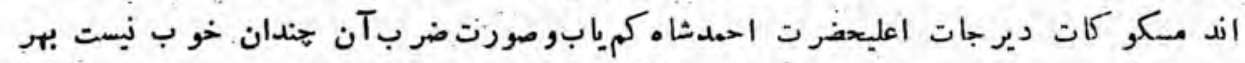

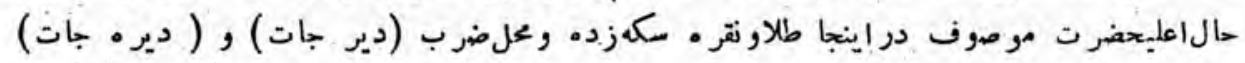

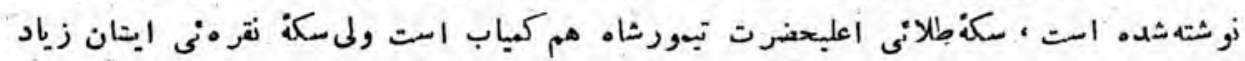

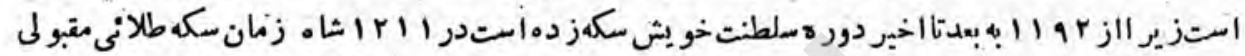

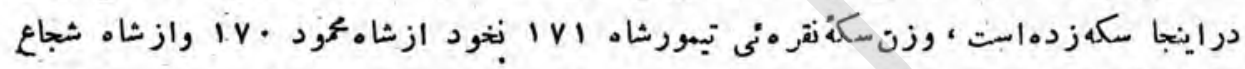

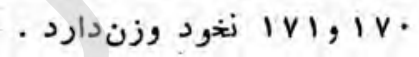

$: \sin$

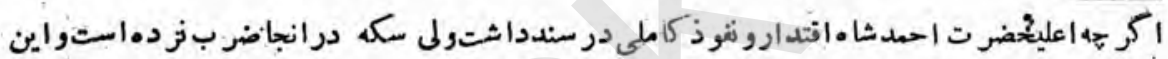

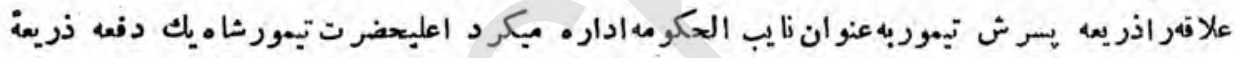

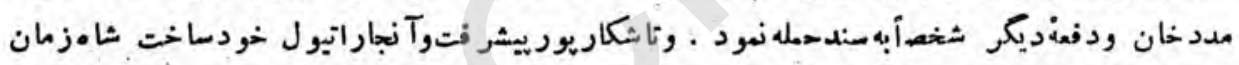

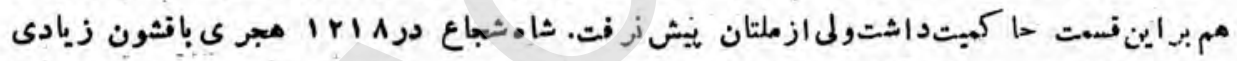

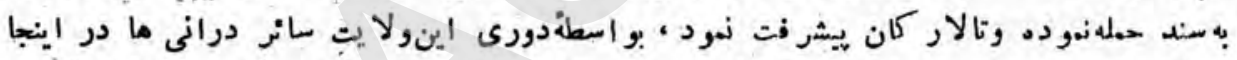

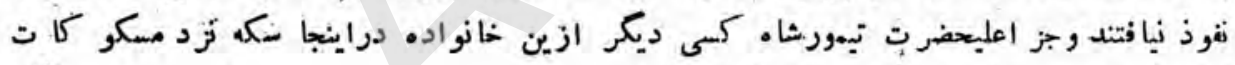

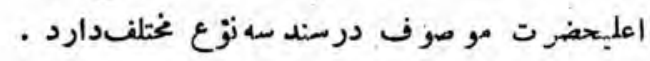

\section{شر هند :}

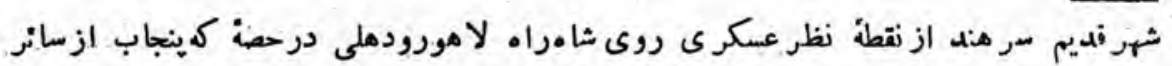

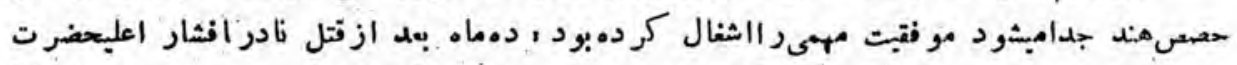

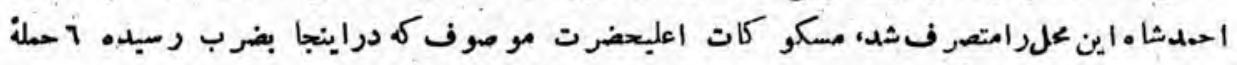

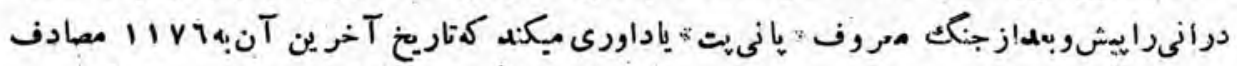

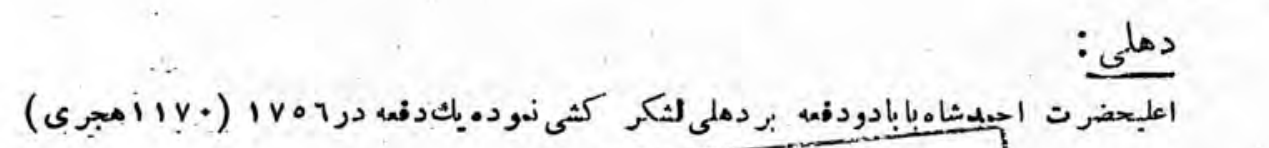
Prof. Dr. R. Nevĩa 


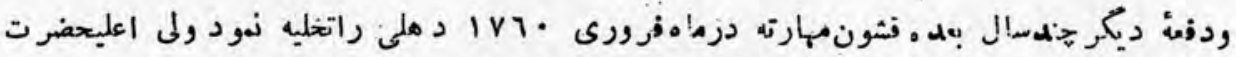

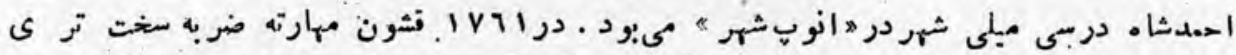

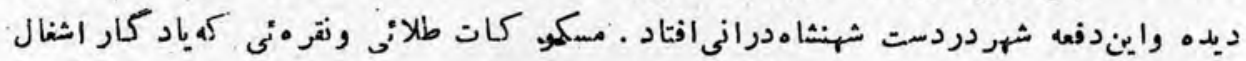

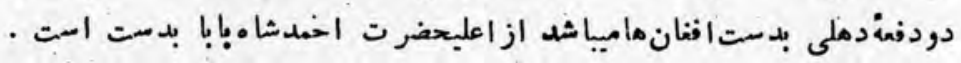

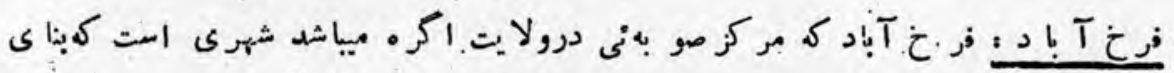

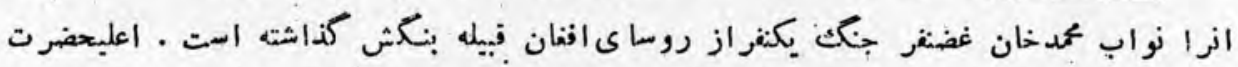

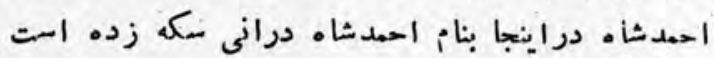

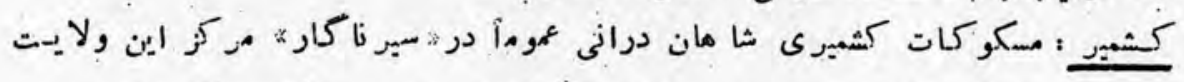

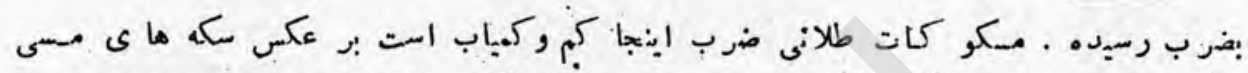

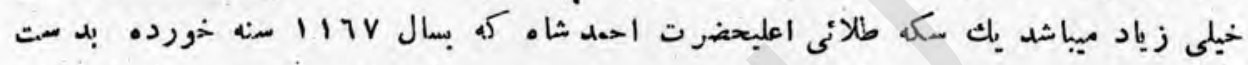

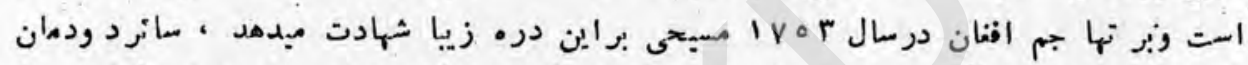

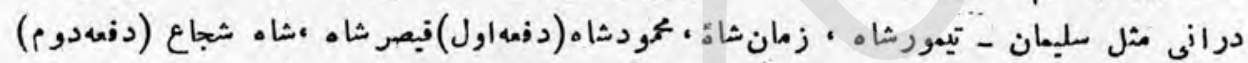

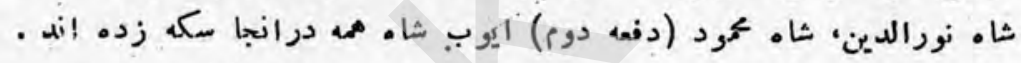

لامور : قثون اعلبحضر ت احهد شاه درانى در r ب جنور ى

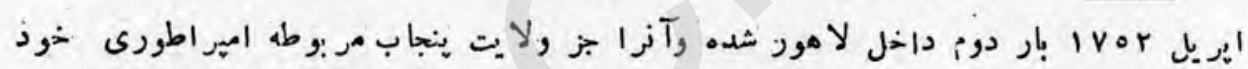

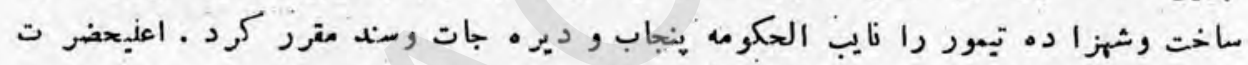

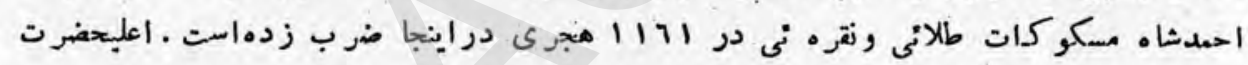

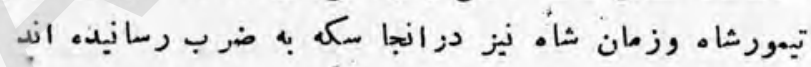

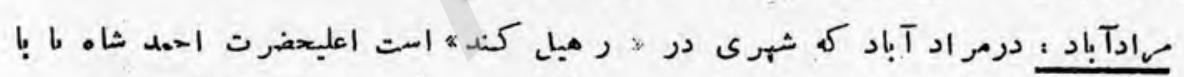

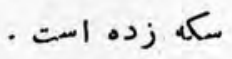

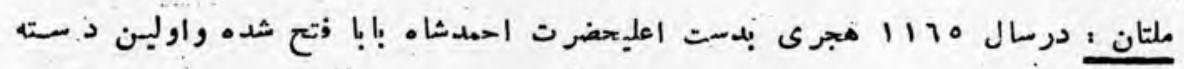

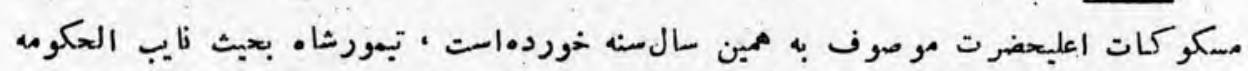

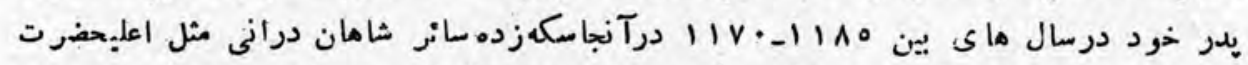

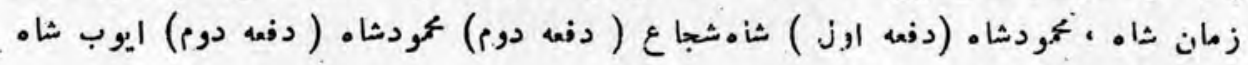

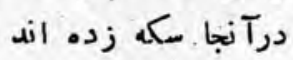
نجيب T با د : درنجيب آباد ك شهرى در صوبه يجنورورلايت اكرك • ا-ت نجب الدوالهخان

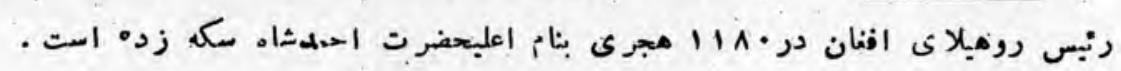


نهو نه مسكو ككات شاهان درانى ".

$$
\text { |عليجضر ت احمد شاه }
$$

سك. طلال محل ضرب انك

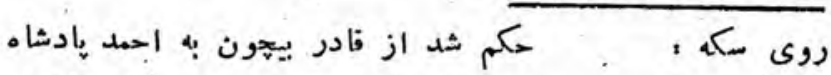

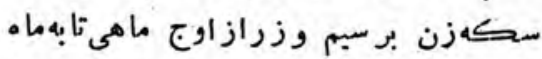

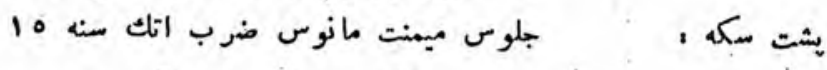

间 畕

$$
\text { سكم نقره }
$$
(1)
分
自

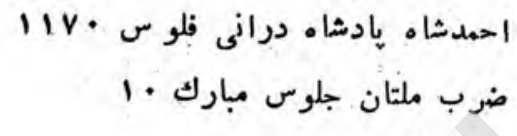

6)
روى سكאه :

بشت سكه : ونه :
سك مسى :

옹

تيمور شاه •نظام ( بجيث نايب الحكو مهنيجابوسند وديره جات

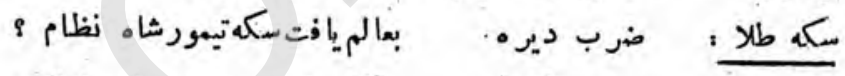

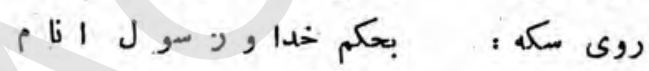

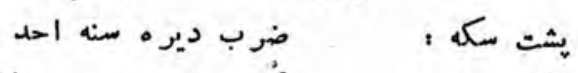

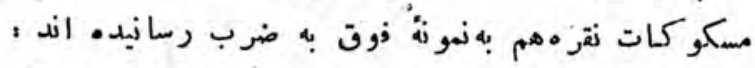

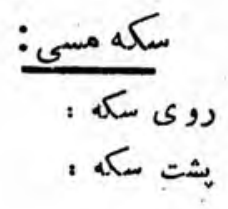

(1)

$$
\text { ضلوب ديره سنه ماهى }
$$

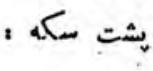

ㄱ. 싱

اعليحضرت تيمورشاه

سكه طلا : ضرب انك

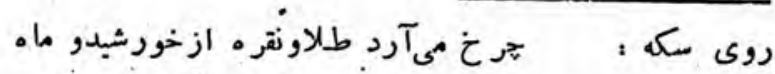

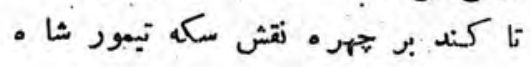




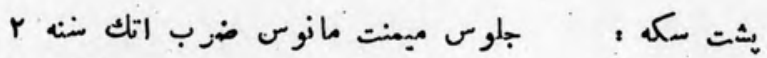

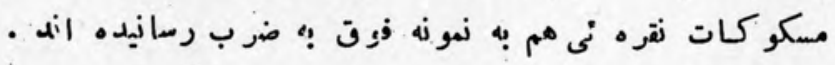

مسكو كات ممبيى :

روى سكه تيهور نشاهى ظلوس

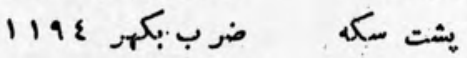

اعليجضرت ت شاه زمان

'.

سكه طال ضرب اشرف البلاد احمد شاهي

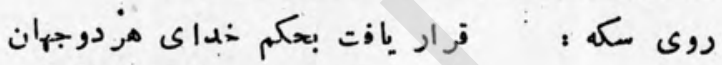

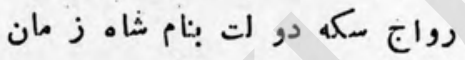

$$
\text { 1r.9 سكت }
$$

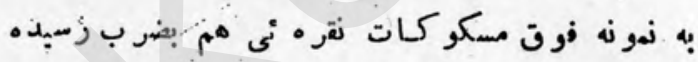

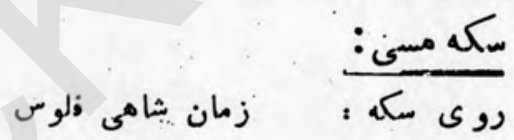

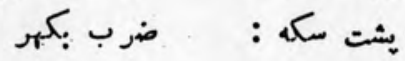

اعليحضوت ممود شاه (در, م,ات)

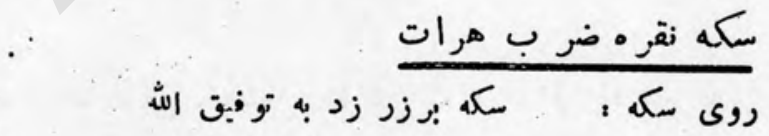

خسروكبتى ستان ميمود شاه

يثت مكه : ضرب دارالسلطنه هرات 14

اعليحفرت محودشاه (سلطنت د فعه اول )

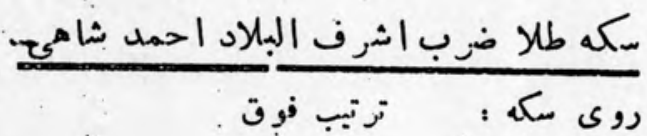

10 


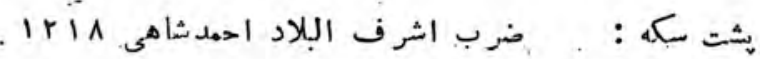

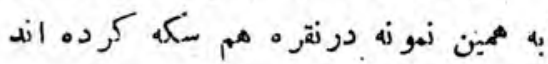

$$
\begin{aligned}
& \text { روى سكه : }
\end{aligned}
$$

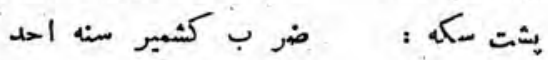

اعليحضرت ت شجا ع الهملك شاه

سكه طلائى ضرب اشرف البلاد احمد شاه.

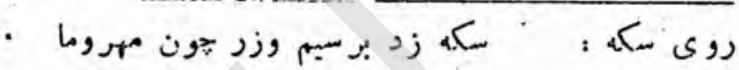

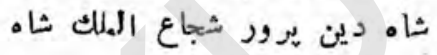

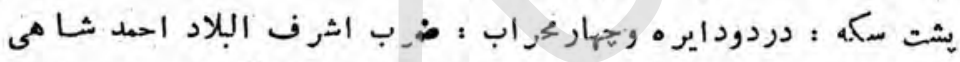

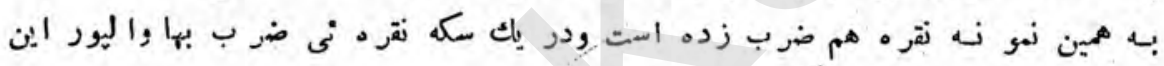

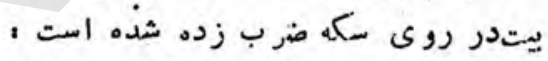

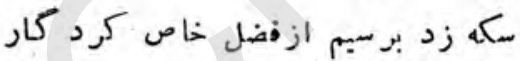

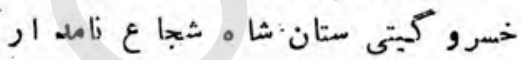

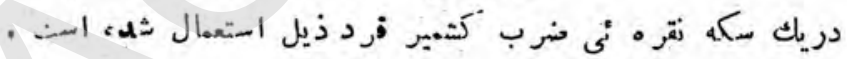

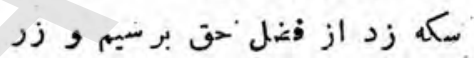

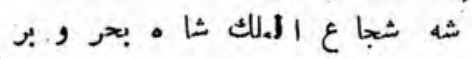

مسكو, كات مسي : (1)

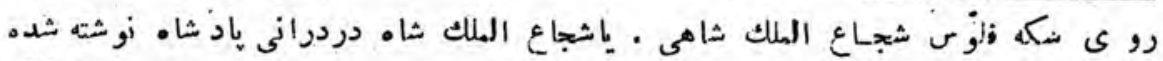

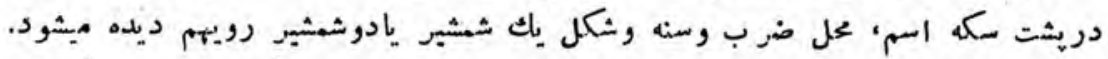

قيصر شاه

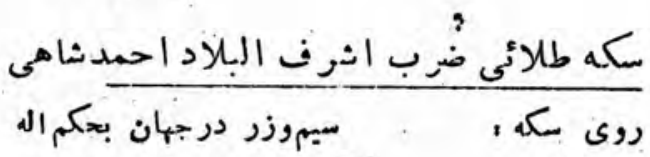

كثت رانج بنام فيعبر شاء

17 


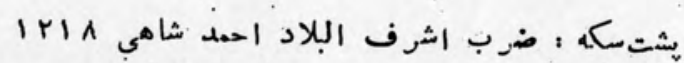

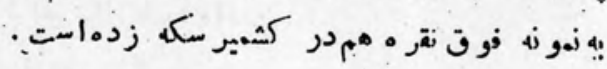

(4)

\section{اعليحضوت محهمودشاه (دوفهدوم)}

اعلنحضرت مكمو: شاه باردوم انبز ظلا ونقره ومس ضرب زده است بيتروى مسكو, كات

$$
\begin{aligned}
& \text { سكندولت بهزرو سيم فزود } \\
& \text { حسن ديكر سلطان محمو دورو } \\
& \text { (1) } \\
& \text { ككه برزر زد به توفيق اله } \\
& \text { خسروى كيتى ستان مكمود شاه }
\end{aligned}
$$

分鲜

$$
\text { شlor }
$$

\section{سكه طلائي ضزب كمهير}

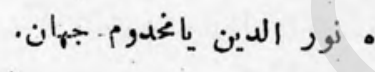

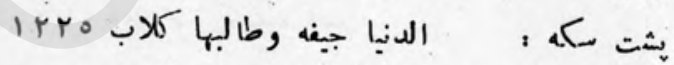

$$
\begin{aligned}
& \text { اين فردرا هم دربعضى سكه استعمال كردهاست است }
\end{aligned}
$$

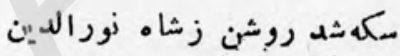

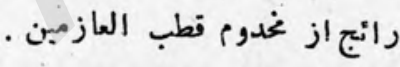

(1)

$$
\text { إي شاه }
$$

$$
\begin{aligned}
& \text { سك+طالأئى ضرب يشاور }
\end{aligned}
$$

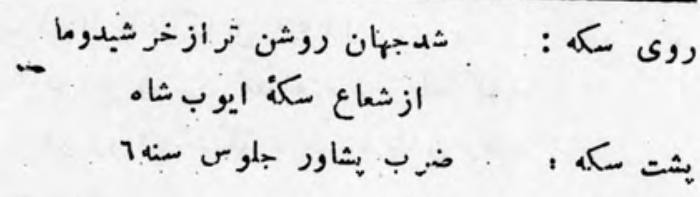


دربعضى مسكو كات نقرنى اين فردرا استعمال نمودهاست

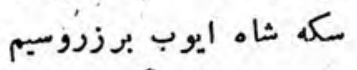
زدبهتائيد كردكار عظيم

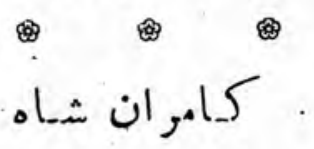

درهرات سكهماى نقرنى به ضر برسانيد

شحام الملفك (دوفعُسو م)

در كابل واحد شاهى طلاو ذقره ضرب زده

6.

فتح جنז

سكهنقر. ضرب كابل:

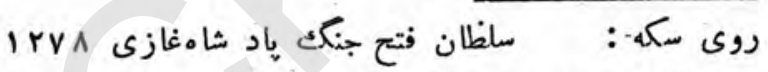

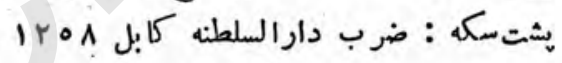

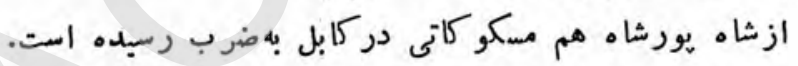
Lحمد زانى

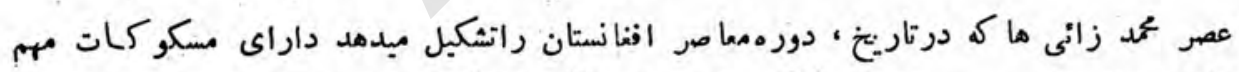

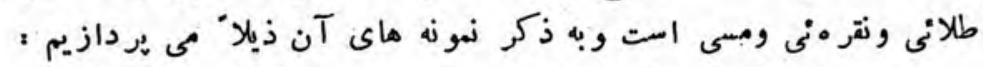

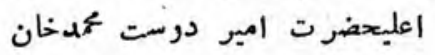

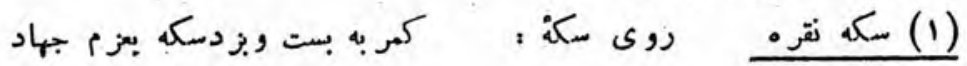

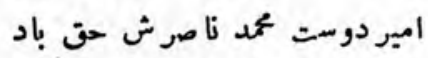

ها

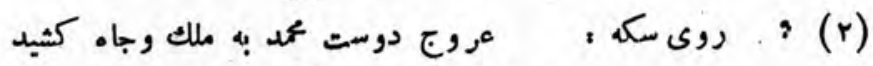

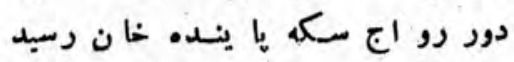

يثت سكه ، بمن معلو م نيست

11 
درسكه هاى اعليحضرت امير دوست ممدخان اين فرد ذيل هم ديده شئه

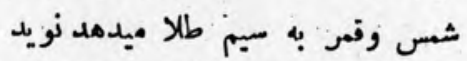

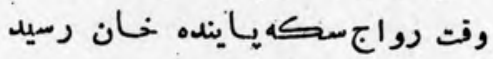

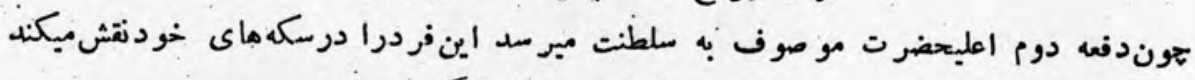

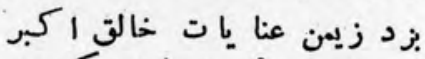

امير دوست محد دوباره سكع برد

(1) (1)

امير شيرعلى خان.

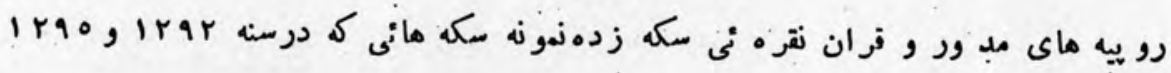

$$
\begin{aligned}
& \text { دركابل ضرب زده ينين است. } \\
& \text { روى سكه : امبر شيرعلى ، دورادورآن كلمه شرينه }
\end{aligned}
$$

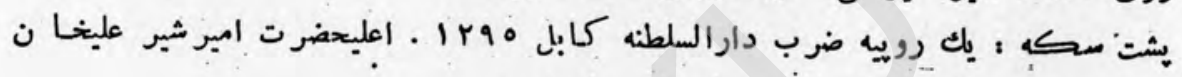

$$
\begin{aligned}
& \text { درسكه ماى خود بعضى افر اد ذيل را نيز نتش نموده : }
\end{aligned}
$$

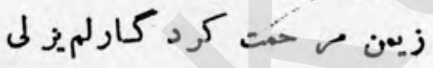

$$
\begin{aligned}
& \text { يافت سكه رواج از امبر شير على }
\end{aligned}
$$

(1) (2)

زالثا ت كثبر 1 مبر نيك ضمير

امير شيرعلى سكه زدجيوبدر منير نير

(1) (1)

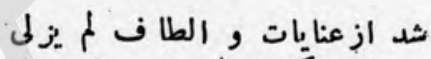

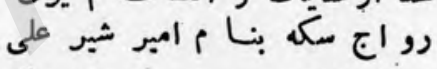

تون دفع دوم به سلطنت ميرسد اين فرد را استعمال ميكند .

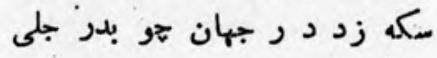

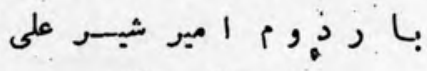

(2)

اميرمحد اعظم خان

$$
\begin{aligned}
& \text { روى سكك : امير بحمد اغظم }
\end{aligned}
$$

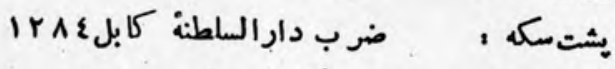

$$
\begin{aligned}
& \text { اين فردمم دربعضى سكنهاى اودنده شدبه }
\end{aligned}
$$


جو ازعنايت الطاف حق ملز مشثد

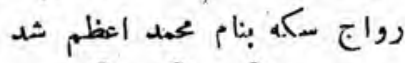

(1)

$$
\text { امير محمد افضلىخان: اين زيردا به مكه هاى اونسبت ميدهند }
$$

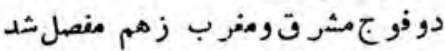

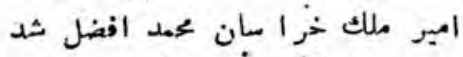

को

$$
\text { اعلديجضرت امير شير عليخان (باردوم) }
$$

اين فرد به ضزب مـكموكات او دردفعه دوم سلطنت اشارهميكند

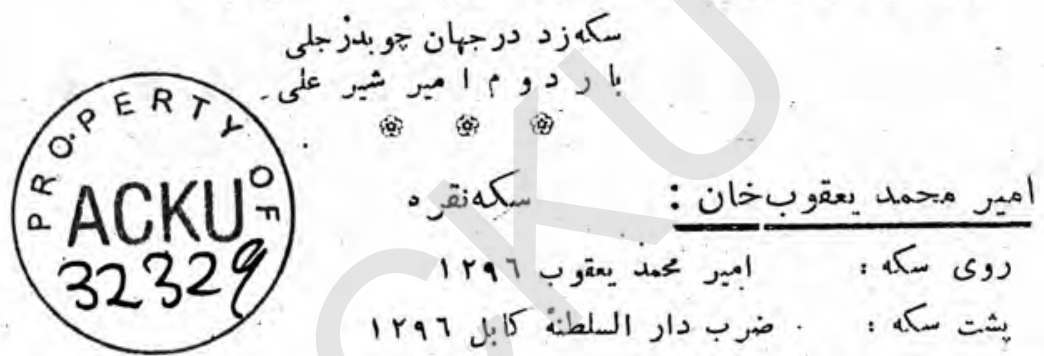

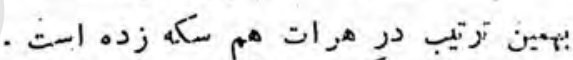

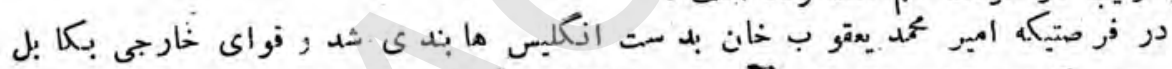

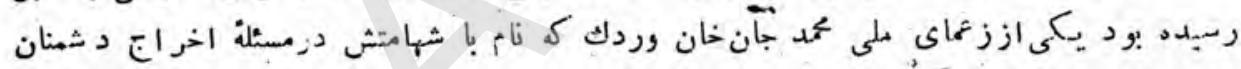

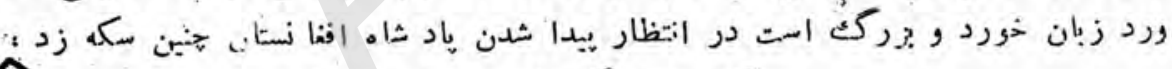

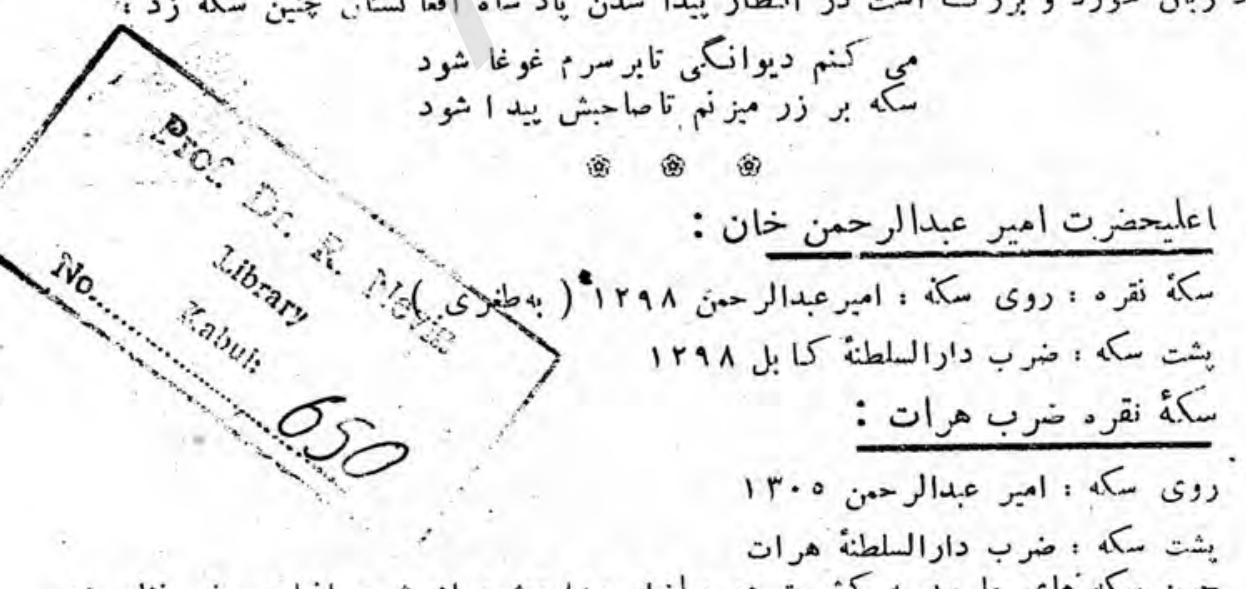

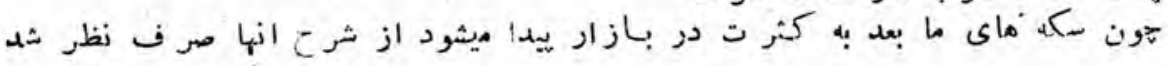




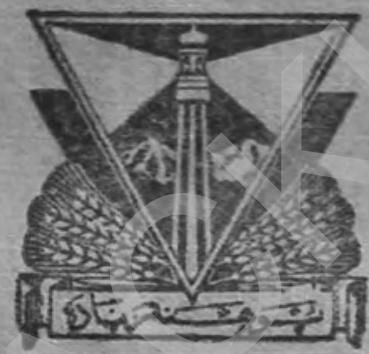

